\title{
Pena e direito penal em Kant: nove teses ${ }^{*}$
}

\section{Punishment and criminal law in Kant: nine theses}

\section{Joachim Renzikowski}

Resumo: Na visão tradicional, Kant, juntamente com Hegel, é considerado um representante proeminente do retributivismo. Com isso, 0 veredicto da insustentabilidade científica da teoria retributiva 0 atinge, juntamente com outras críticas em torno de sua teoria do direito penal. No entanto, uma leitura atenta de sua teoria do direito oferece uma imagem muito mais refinada. A teoria da pena de Kant é de importância atemporal e antecipa em parte conceitos modernos, tais como pena e culpabilidade. Para compreendê-la, não se pode escolher apenas algumas passagens, como é usual, mas, sim, necessita-se tomar conhecimento de "toda" a doutrina do Direito. Neste artigo, o delineamento da teoria penal de Kant será apresentado em nove teses, confirmadas com as passagens de texto pertinentes.

Palavras-chave: imperativo categórico; imputação; princípio da legalidade; retribuição; Estado de Direito.

Abstract: In the traditional view, Kant, along with Hegel, is considered a prominent representative of retributivism. With this, the verdict of the scientific unsustainability of the retributive theory hits him, as well as other criticisms concerning his theory of criminal law. However, a close reading of his theory of law offers a much more differentiated picture. Kant's theory of punishment is of timeless relevance and anticipates in part modern concepts such as punishment and blame. In order to understand it, one cannot choose just a few statements, as is usual, but rather, one needs to be aware of the "whole" doctrine of Law. In this paper, the outline of Kant's penal theory will be presented in nine theses, confirmed with the relevant text passages.

Keywords: categorical imperative; imputation; principle of legality; retribution; State of Law.

Sumário: Introdução; 1 Primeira tese: a missão do Estado de Direito é garantir a liberdade dos cidadãos contra "0 arbítrio compulsivo de outrem, segundo uma lei universal", por meio do Direito; 2 Segunda tese: Como os motivos do destinatário da norma não são objeto do Direito, a coerção mantém-se como sendo o único meio para influenciar 0 comportamento; 3 Terceira tese: Por meio do crime 0 criminoso não apenas lesiona 0 direito subjetivo da vítima, mas também questiona a ordem jurídica como tal; 4 Quarta tese: Retribuição não significa nada mais do que impor um mal ao delinquente pela prática de um ilícito culpável. Retribuição não é um fim da pena, mas simplesmente a definição

\footnotetext{
* Manuscrito inédito. Tradução de Beatriz Corrêa Camargo e Wagner Marteleto Filho.
}

RENZIKOWSKI, Joachim. Pena e direito penal em Kant: nove teses. Trad. Beatriz Corrêa Camargo e Wagner Marteleto Filho. Revista do Instituto de Ciências Penais, Belo Horizonte, v. 7, n. 1, p. 1-23, 2022. 
da pena; 5 Quinta tese: A imputação de um delito contém uma censura jurídica; 6 Sexta tese: Se 0 Estado ameaça determinado comportamento com a punição, ele também é obrigado de forma absoluta a aplicar a lei penal; 7 Sétima tese: Uma exceção cabe apenas se, de modo evidente, a coação cominada não puder preencher 0 seu objetivo; 8 Oitava tese: A oposição entre teorias retributivas e preventivas é um problema aparente; 9 Nona tese: A medida da pena se orienta pelo ilícito e neste aspecto a culpabilidade é contingente; Conclusão; Referências.

\section{Introdução}

Kant é habitualmente considerado como um defensor da teoria retributi$\mathrm{va}^{1}$. Com isso, o veredicto da insustentabilidade científica da teoria retributiva o atinge, pois a ideia de retribuição desconsidera todos os objetivos sociais e exige também a pena ali onde ela não é necessária à pretensão de proteção do bem jurídico. Assim, critica-se que, nesse caso, a pena perderia toda sua legitimação social. Ademais, considera-se que o Estado não estaria autorizado a realizar uma "ideia metafísica de justiça". Por fim, a concepção de uma pena que sirva exclusivamente para a retribuição da culpabilidade seria inaceitável, porque a culpa individual se vincula à existência do livre-arbítrio, cuja indemonstrabilidade o torna inadequado como fundamento único da intervenção penal ${ }^{2}$. Tal avaliação de Kant tornou-se bastante difundida desde o "adeus" a Kant por Ulrich Klug, no ano de $1968^{3}$. Contudo, como se demonstra a seguir, ela tem muito pouco a ver com Kant.

Aliás, muito pelo contrário: a Metafísica dos costumes, de Kant ${ }^{4}$ (1797), contém uma teoria da pena bastante sofisticada e de uma qualidade atemporal. Para trabalhá-la, não se pode escolher apenas alguns pontos, como é usual, mas, sim, necessita-se tomar conhecimento de "toda" a Doutrina do Direito. Isso se refere especialmente às manifestações de Kant sobre o direito subjetivo, sobre a função do Direito e sobre a missão do Estado de Direito5. A seguir, o delineamen-

1 Veja, por todos, ROXIN, Strafrecht AT I, § 3 nm. 3.

2 ROXIN, ob. cit. (nota 1), § 3 nm. 8; de forma semelhante, MK-JOECKS, Einl., nm. 54 ("não mais defensável"); SCHÜNEMANN, FS-Lüderssen, p. 332: "beco sem saída"); STRATENWERTH, Was leistet die Lehre von den Strafzwecken?, p. 9 ("posição marginal"). Existem, é claro, novas vozes a esse respeito - veja-se, por todos, PAWLIK, Person, Subjekt, Bürger, p. 45 e ss.

3 KLUG, Programm für ein neues Strafgesetzbuch, p. 36-41.

4 KANT, Metaphysik der Sitten, p. 203-493, a seguir citado no texto como "AA VI" com a indicação da página. Nota dos tradutores (NT): Para as passagens da obra de Kant a que se refere Joachim Renzikowski, foram utilizadas as respeitadas traduções portuguesas da Editora Calouste Gulbenkian, indicadas nas referências ao final.

5 Nesse sentido, HAAS, Strafbegriff, Staatsverständnis und Prozessstruktur, p. 182 e ss., se refere a outras passagens da obra de Kant, mais especificamente a "Crítica da razão prática" ("Kritik der praktischen Vernunft") e "A religião nos limites da simples razão" ("Religion innerhalb den Grenzen der bloßen Vernunft") como provas 
to da teoria penal de Kant deve ser apresentado em nove teses, confirmadas com as passagens de texto pertinentes ${ }^{6}$.

\section{Primeira tese: A missão do Estado de Direito é garantir a liberdade dos cidadãos contra "0 arbítrio compulsivo de outrem, segundo uma lei universal", por meio do Direito}

A teoria penal de Kant se encontra na segunda parte da Doutrina do Direito, com o título "Do Direito Penal e do direito de graça", no parágrafo sobre o direito público ${ }^{7}$. A relação sistemática da Metafísica dos costumes demonstra que Kant não se ocupou de um Direito Penal qualquer de uma ordem jurídica qualquer. $\mathrm{O}$ seu tema é, sobretudo, um Direito Penal liberal em um Estado de Direito, que começa a partir da liberdade do indivíduo como liberdade juridicamente protegida.

Essa liberdade, entendida como "a independência em relação a um arbítrio compulsivo de outrem", é o "direito único, originário, que corresponde a todo o homem em virtude da sua humanidade" ${ }^{\prime \prime}$. Obviamente, esse direito (subjetivo) não é ilimitado, mas, sim, encontra sua fronteira na liberdade de cada um dos outros. É tarefa do Direito - agora entendido, ao mesmo tempo, como conjunto de normas jurídicas - determinar o alcance deste direito (subjetivo) de liberdade.

O Direito é, pois, o conjunto das condições sob as quais o arbítrio de cada um pode conciliar-se com o arbítrio de outrem segundo uma lei universal da liberdade. ${ }^{9}$

Consequentemente, diz "o princípio geral do Direito":

de uma teoria retributiva absoluta. De fato, uma passagem correspondente também se encontra na "Metafísica dos costumes" ("Metaphysik der Sitten"). Nesse sentido, o seguinte trecho do § 36 da "Doutrina da Virtude" ("Tugendlehre"), AA VI, p. 460: "Toda a ação que cause prejuízo ao direito de uma pessoa merece castigo, por intermédio do qual se vingue o delito no autor da ação". Conforme considera Kant em seguida, "ninguém tem o direito de impor castigos e vingar a ofensa sofrida pelos homens, a não ser aquele que é também o supremo legislador moral (quer dizer, Deus), e só este pode dizer: 'a vingança é minha; quero ser eu a exercer a vingança'”. Contudo, é preciso distinguir estritamente, como faz Kant, entre a pena divina e a "pena judicial (poena forensis)", da qual se trata exclusivamente na "Doutrina do Direito" ("Rechtslehre").

As formulações que se seguem não reivindicam originalidade. Cf., por ex., as apresentações elaboradas por ALTENHAIN, GS-Rolf Keller, p. 1-13; e HRUSCHKA, FS-Puppe, p. 17-37. 
Uma ação é conforme ao Direito quando permite ou quando a sua máxima permite fazer coexistir a liberdade do arbítrio de cada um com a liberdade de todos segundo uma lei universal. ${ }^{10}$

Evidentemente, a proteção jurídica só é possível em um Estado de Direito. Para Kant, o Estado de Direito não é apenas um Estado que formula leis para si e que direciona as ações de seus órgãos e cidadãos segundo as leis. Essas leis servem sobretudo a um objetivo: a proteção da liberdade - o que, em si, não constitui grande novidade.

O estado jurídico é aquela relação dos homens entre si que engloba as condições sob as quais exclusivamente pode cada um participar do seu direito. ${ }^{11}$

Uma vez que fora de um Estado de Direito - portanto, em um tradicionalmente denominado "estado de natureza" - nenhuma segurança jurídica é garantida, todos são levados, por motivos racionais, a superar o "estado de natureza".

Do Direito privado no estado de natureza [isto é, o direito, de ter algo como meu ${ }^{12}$ surge, então, o postulado do Direito público: deves, numa relação de coexistência inevitável com todos os outros, sair do estado de natureza para entrar num estado jurídico, quer dizer, num estado de justiça distributiva. ${ }^{13}$

Dessa forma, constitui-se o Estado de Direito:

Um Estado (civitas) é a união de um conjunto de pessoas sob leis jurídicas. Na medida em que estas, como leis a priori, são necessárias, ou seja, resultam por si dos conceitos do direito externo em geral (não são estatutárias), a sua forma é a forma de um Estado em geral, i.e., do Estado ideal, tal como ele deve ser segundo os puros princípios do Direito, ideia essa que serve de norma (norma) a toda a associação efectiva dirigida a constituir um corpo político. ${ }^{14}$

Kant desenvolve em sua Metafísica dos costumes não apenas o modelo de um Estado de Direito liberal, mas já toma, antecipadamente, considerações que serão formuladas pela "teoria pessoal do bem jurídico" duzentos e setenta anos 
depois: o Direito Penal somente é legítimo na medida em que ele sirva à proteção de cada um e sirva às instituições estatais necessárias para isso ${ }^{15}$. Um Direito Penal que desconsidere todos os objetivos sociais não é concebível para Kant ${ }^{16}$.

\section{Segunda tese: Como os motivos do destinatário da norma não são objeto do Direito, a coerção mantém-se como sendo o único meio para influenciar o comportamento}

Todas as leis, para que possam ser práticas, são dirigidas a determinar o arbítrio. Kant fala em "fundamentos internos de determinação"17. No entanto, podem-se distinguir duas espécies de legislação:

A legislação que faz de uma ação um dever e simultaneamente desse dever um móbil [de ação] é ética. Mas a que não inclui o último na lei e que, consequentemente, admite um móbil diferente da ideia do próprio dever é jurídica. No que respeita a esta última, vemos facilmente que estes móbiles, distintos da ideia de dever, têm que extrair-se dos fundamentos patológicos da determinação do arbítrio, das inclinações e das aversões, e, de entre estas, das últimas, porque tem que ser uma legislação que seja compulsiva e não um engodo convidativo. [...]

Os deveres decorrentes da legislação jurídica só podem ser deveres externos, porque esta legislação não exige que a ideia de dever, que é interna, seja por si mesma fundamento de determinação do arbítrio do agente e uma vez que ela necessita precisamente de um móbil conforme à lei só pode ligar à lei móbiles externos. ${ }^{18}$

A distinção entre moral e norma jurídica associada a essa ideia, ou seja, entre "moralidade" e "legalidade", é importante de duas perspectivas. Primeiro, as razões ou motivações internas não possuem qualquer papel para a recíproca delimitação das esferas jurídicas. Apenas por meio de maus pensamentos não é lesado o direito de outrem. Em segundo lugar, é fato que as regras jurídicas também apelam à vontade do destinatário da norma, mas a ordem jurídica não exige dele qualquer boa vontade. As razões determinantes (ou "fundamentos internos

15 Veja, por ex., MARX, Zur Definition des Begriffs "Rechtsgut", p. 68 e ss.; de modo semelhante, ROXIN, ob. cit. (nota 1), § $3 \mathrm{~nm} .7$.

16 Nesse sentido a acusação genérica feita por ROXIN, ob. cit. (nota 1), $\$ 3 \mathrm{~nm}$. 8, a qual já fica muito aquém do verdadeiro problema na medida em que as chamadas "teorias de prevenção" não podem especificar, por sua vez, quais bens jurídicos seriam capazes de legitimar o uso do direito penal e, nesse tocante, dependem de pressupostos adicionais. 
de determinação") das ações podem ser analisadas, mas não comprovadas em relação à sua existência ${ }^{19}$.

Só pode, portanto, chamar-se Direito estrito (Direito em sentido mais restringido) ao Direito completamente externo. Este fundamenta-se, na verdade, na consciência da obrigação de cada um segundo a lei; mas, para determinar o arbítrio em conformidade com ela, não the é lícito nem pode, se é que deve ser puro, apelar a esta consciência como móbil; apoia-se, isso sim, no princípio da possibilidade de uma coerção exterior, que pode coexistir com a liberdade de cada um segundo leis universais. ${ }^{20}$

Quem, já por si mesmo, pela própria convicção (moral), se comporta de modo leal ao direito, não necessita, em princípio, de qualquer instrução adicional por meio da lei ${ }^{21}$. A lei é necessária, portanto, especialmente para os seres racionais cujas razões determinantes são "patológicas", já que incompatíveis com a liberdade de todos, segundo uma lei geral. Na medida em que tais seres não se deixam determinar desde o início pela via da representação do dever de um comportamento correto, apenas a coerção jurídica - isto é, a força - os ajuda a fazê-lo. A relação entre Direito e uso da força é fundamental para Kant. Assim, está "ao mesmo tempo associada ao Direito uma faculdade de coagir aquele que Ihe causa prejuízo, de acordo com o princípio de não contradição" ${ }^{\prime 22}$. Sem proteção jurídica pela força, o Direito não é sequer concebível ${ }^{23}$. Nesse sentido, Kant

19 Cf. KANT, Kritik der reinen Vernunft, p. 373, nota de rodapé: "A moralidade própria das ações (o mérito e a culpa), mesmo a da nossa própria conduta, fica-nos, pois, completamente oculta. As nossas imputações podem apenas reportar-se ao carácter empírico". Em sentido semelhante, já considerava TOMÁS DE AQUINO, Summa Theologica, la Ilae, qu. XCI, art. IV, co.: "Quia de his potest homo legem ferre, de quibus potest iudicare. Iudicium autem hominis esse non potest de interioribus motibus, qui latent, sed solum de exterioribus actibus, qui apparent. Et tamen ad perfectionem virtutis requiritur quod in utrisque actibus homo rectus existat. Et ideo lex humana non potuit cohibere et ordinare sufficienter interiores actus [...]". Disso resultam dificuldades fundamentais para aquelas posições que, como a prevenção geral positiva, enfatizam a educação das consciências - veja-se, por exemplo, FRISCH, FS-Schünemann, p. 63 ss. Naturalmente, tal objetivo é muito bem-vindo, mas apenas pode ser tido por um efeito colateral, uma vez que o direito (penal) estaria completamente sobrecarregado com a expectativa de ser uma espécie de escola moral da população.

20 KANT, AA VI, p. 232.

21 Já, nesse sentido, AUGUSTINUS, De libero arbitrio, I.15, 31, ou, também, AQUIN, ST, la llae, qu. XCVI, art. V, co.: "Et hoc modo homines virtuosi et iusti non subduntur legi, sed soli mali". Naturalmente, não se pode confiar nisso, pois, "por muito que queira imaginar-se os homens como bons e amantes do Direito, esta está sim ínsita a priori na ideia racional de um tal estado (do estado não-jurídico), que até que seja edificado um estado legal público, os homens, povos e Estados isolados não podem nunca estar seguros face à violência de uns contra os outros..." (AA VI, p. 312).

23 Com mais detalhes, RIPSTEIN, JRE 16, p. 232 ss. Isso pode ser compreendido, sem dúvidas, no sentido de uma justificativa individualista de autodefesa - cf., por exemplo, RENZIKOWSKI, Notstand und Notwehr, p. 230 ss.; 
considera que as recompensas são inadequadas porque não se trata de ensinar determinada atitude, mas sim de compelir a determinado comportamento. Além disso, as recompensas são reservadas para aqueles que fazem mais do que precisam fazer em virtude do Direito ${ }^{24}$.

A partir de tais premissas, Feuerbach veio a desenvolver a sua teoria da coação psicológica tempos depois ${ }^{25}$. Digno de nota é que Feuerbach costuma ser apresentado em oposição a Kant, sendo considerado um proeminente defensor da prevenção geral ${ }^{26}$. Em realidade, Feuerbach foi um kantiano confesso, que quis fazer da filosofia de Kant algo frutífero para a práxis do Direito Penal e para a legislação penal. Isso, por si só, sugere que é apenas aparente a oposição que comumente se faz entre a prevenção geral e a posição kantiana. Mais ainda: Feuerbach acentua, sobretudo, o poder de controle de comportamentos pela lei - como também o faz Kant. Nessa medida, porém, não se trata, em absoluto, de uma particularidade da lei penal. Todas as leis objetivam controlar comportamentos. Isso porque elas prescrevem um dever e estabelecem uma consequência jurídica para sua inobservância ${ }^{27}$. Quem assina um contrato de compra também deve confiar que pode implementar sua pretensão judicialmente, por meio de uma execução judicial, caso necessário. Inversamente, a ameaça de execução judicial deve encorajar o devedor inadimplente a saldar sua dívida, se nada mais funcionar. No entanto, as leis somente conseguem manter a sua autoridade se elas também forem aplicadas.

contudo, no Estado Democrático de Direito, o Estado é o principal responsável pela proteção jurídica e, portanto, também pela coerção.

24 Acerca da Supererrogação, veja HRUSCHKA/JOERDEN, ARSP 73, p. 93-123.

25 Elaborado em detalhe em FEUERBACH, Revision der Grundsätze und Grundbegriffe des positiven peinlichen Rechts, p. 43 ss.; veja, ainda, FEUERBACH, Lehrbuch des gemeinen in Deutschland gültigen peinlichen Rechts, $\S \S 10 \mathrm{ss}$.

26 Assim, por exemplo, ROXIN, ob. cit. (nota 1), § 3 nm. 22. A propósito: é absurdo que Feuerbach também seja apontado como representante de uma concepção determinista.

27 É inútil discutir se esta ideia não está ultrapassada por que uma abordagem de escolha racional não seria adequada para o Direito Penal: muitos criminosos não agem de forma deliberada - nesse sentido, a crítica de JAKOBS, Strafrecht AT, 1/28; e ROXIN, ob. cit. (nota 1), § 3 nm. 25 sobre prevenção geral negativa. Não se pode esperar mais de uma lei do que fornecer uma razão (prudencial) adicional, além de outros motivos sensórios. Cf., sobre isso, igualmente, GRECO, Lebendiges und Totes in Feuerbachs Straftheorie, p. 359 ss. 


\section{Terceira tese: Por meio do crime o criminoso não apenas lesiona o direito subjetivo da vítima, mas também questiona a ordem jurídica como tal}

Da inversão do "princípio geral do Direito" antes exposto resulta que uma ação é injusta se a sua máxima não compatibiliza a liberdade do arbítrio de um com a liberdade de todos, segundo uma lei geral - com outras palavras: se ela viola o direito de outrem ${ }^{28}$. No entanto, a violação de um direito pode ser vista de duas perspectivas distintas: uma "formal", sobre a violação do direito subjetivo, e outra "material", relativa à violação da lei estatal, que deve garantir tal direito. Quem pratica um ato punível retira "toda a validade ao próprio conceito de Direito" $^{29}$, pois:

qualquer transgressão da lei pode explicar-se do seguinte modo e de nenhum outro: que a transgressão tem origem numa máxima do delinquente (a máxima de se dar a si próprio tal crime como regra) $[\ldots]^{30}$

A ideia de que o crime corresponde a uma máxima significa que o criminoso a determinou para si mesmo por meio de seu livre-arbítrio, pois, de outro modo, o ato não poderia ser imputado a ele ${ }^{31}$. Porém, a máxima de ação delitiva, como é fácil de se ver, vai no sentido de contrariar a máxima preestabelecida pela lei. Kant demonstra isso por meio do exemplo do furto:

Aquele que rouba torna insegura a propriedade de todos os demais. ${ }^{32}$

O criminoso desconsidera não somente o direito de propriedade da vítima, mas a propriedade enquanto instituto jurídico - como se a proibição do furto não valesse para ele ${ }^{33}$.

28 Em referência a isso, Feuerbach desenvolve mais tarde a sua teoria do delito como violação de direitos - cf. FEUERBACH, Lehrbuch (ob. cit., nota 25), § 21: "Quem transgride os limites da liberdade jurídica, comete uma violação de direitos, uma injúria (lesão). Quem viola a liberdade garantida pelo contrato estatal e garantida pelas leis penais, comete um crime".

KANT, AA VI, p. 308, nota de rodapé do $\$ 42$.

30 KANT, AA VI, p. 321, nota de rodapé da antoação geral A do § 49.

31 Kant chama a capacidade de estabelecer máximas para as próprias ações de livre-arbítrio (cf. AA VI, p. 213 e s.); esse arbítrio é um pré-requisito para os juízos de imputação (sobre isso, ver a seguir) e torna o sujeito em questão uma "pessoa" (AA VI, p. 223).

32 KANT, AA VI, p. 333. NT: Como mencionamos na primeira na nota de tradução, as passagens de Kant foram extraídas da tradução portuguesa de José Lamego. Isso explica por que Renzikowski se refere ao crime de furto, ao passo que o trecho traduzido de Kant utiliza o verbo "roubar" de maneira juridicamente atécnica.

Veja-se, a respeito, RIPSTEIN, ob. cit. (nota 23), p. 240 ss. 
Assim, embora cada violação ao Direito contenha esses dois aspectos, a violação, por si só, não exige ainda a intervenção do Direito Penal. A esse respeito, Kant distingue, sobretudo, a "violação da lei pública que incapacita aquele que a comete de ser cidadão" ${ }^{34}$, diferenciando-a de outras violações. A violação da lei pública ele designa "pura e simplesmente, crime (crimen)", ou, ainda, "crime público (crimen publicum)". Por meio dessa violação é colocada em risco "toda a comunidade, e não uma única pessoa apenas".

Para julgar a violação de uma lei pública, é competente apenas a "justiça criminal", ao passo que os "delitos privados" devem ser julgados por tribunais civis $^{35}$. Desde que a comunidade, isto é, a ordem jurídica estatal em si mesma, seja afetada, faz-se necessária uma reação estatal, a qual confirma a validade da ordem jurídica em face da máxima do delinquente, a ser esclarecida como irrelevante ${ }^{36}$.

\section{Quarta tese: Retribuição não significa nada mais do que impor um mal ao delinquente pela prática de um ilícito culpável. Retribuição não é um fim da pena, mas simplesmente a definição da pena}

Kant define o Direito Penal como:

[...] o direito que tem o soberano relativamente àquele que lhe está subordinado de lhe infligir um castigo em razão do seu delito ${ }^{37}$.

Como facilmente se extrai do trecho acima, a ideia de "soberano" não tem como significado um soberano qualquer, o qual, segundo seu arbítrio, poderia maltratar seus súditos com punições. De relance, até se poderia compreender algo nesse sentido tendo em vista a formulação seguinte de Kant, quando afirma que "o chefe supremo do Estado" não pode ser punido ${ }^{38}$; contudo, tal leitura seria muito limitada.

O soberano no Estado que Kant tem em mente - e que, note-se, é um Estado de Direito - não é qualquer pessoa individual, mas sim representa a comunidade daqueles que, por meio de uma vontade associada, adentraram um estado de

35 KANT, AA VI, p. 331. Mais sobre isso e sobre a origem histórica dessa distinção, HRUSCHKA, FS-Stöckel, p. 88 ss.

36 Veja RIPSTEIN, ob. cit. (nota 23), p. 243 s.

37 KANT, AA VI, p. 331.

38 KANT, AA VI, p. 331. 
juridicidade ${ }^{39}$. Assim, fica claro que "a união de um conjunto de pessoas sob leis jurídicas" ${ }^{\prime 40}$ não se submete, como tal, à lei penal.

A pena é simplesmente a dor infligida ao criminoso em virtude de seu crime. Em nenhum lugar do capítulo "E. Do direito penal e do direito de graça" Kant sugere que a imposição de um mal (a "dor") constitui um objetivo situado fora da pena, a ser buscado por seu intermédio de maneira específica.

O fundamento para a aplicação da pena é que alguém "cometeu um crime $^{\text {"41 }}$. Disso decorrem duas coisas. Um crime é, segundo Kant, a "violação de uma lei pública"42. Isso nada mais é do que o princípio constitucional do nulla poena sine lege (art. 103, inciso II, GG [Grundgesetz, Lei Fundamental alemã]). Somente deve ser punido um ato que, no momento de sua perpetração, esteja legalmente estabelecido como ato punível. Pública é uma lei que se tornou conhecida pela coletividade ${ }^{43}$. Somente então a lei obtém sua força vinculante. Apenas uma ameaça penal conhecida pelo cidadão pode lhe oferecer uma razão de prudência para se abster do comportamento criminoso ${ }^{44}$.

Isso pressupõe, contudo, a aptidão da lei para direcionar a ação do cidadão por meio de suas razões determinantes, isto é, por meio de sua capacidade de imputação. E com isso chegamos à quinta tese: apenas atua criminosamente alguém a quem o crime possa ser imputado.

\section{Quinta tese: A imputação de um delito contém uma censura jurídica}

Novas teorias da pena situam a censura no ponto central de suas considerações. Segundo alguns autores contemporâneos, a função da pena seria desaprovar o comportamento falho do criminoso ${ }^{45}$. Comparável com isso é o discurso tradicional da pena como "desaprovação ético social"46 - apenas que, aqui, não

39 KANT, AA VI, p. 311. Cf. RIPSTEIN (nota 23), p. 237.

40 KANT, AA VI, p. 313.

41 KANT, AA VI, p. 331.

42 KANT, AA VI, p. 331.

43 KANT, AA VI, p. 311: "O conjunto de leis que precisam de ser universalmente promulgadas para produzir um estado jurídico é o Direito público".

44 Com base nesse raciocínio, FEUERBACH, Lehrbuch (ob. cit., nota 25), § 20, apóia a elaboração que oferece para o princípio de que "não há pena sem lei".

45 VON HIRSCH, Strafe - Warum?, p. 49 ss.

46 Cf. BVerfGE 27, p. 18 (29); 96, p. 245 (249); JESCHECK/WEIGEND, Lehrbuch des Strafrechts AT, p. 65; com maiores referências, KÜHL, ZStW 116, p. 876 ss. 
se trata de uma forma qualquer de ética social, senão de uma desaprovação jurídica, a partir do Direito.

Também nesse respeito descobre-se em Kant um pensamento de vanguarda. Segundo sua conhecida definição:

Imputação (imputatio) em sentido moral é o juízo por meio do qual alguém é considerado como autor (causa libera) de uma ação, que então se chama ato (factum) e está submetido a leis; se o juízo, por seu turno, acarreta consigo as consequências jurídicas do ato, é uma imputação com força jurídica (imputatio iudiciaria s. valida) [...]. ${ }^{47}$

Imputação significa, primeiramente, que um ato se originou do livre-arbítrio ${ }^{48}$. Na terminologia jurídico-penal, isso significa que o ato pode ser imputado à culpabilidade. $\mathrm{O}$ indivíduo que tem a faculdade legal de imputar com força vinculante é o juiz.

Os juízos de imputação são emitidos tendo-se em vista - tão somente - se a ação contrariou uma norma. Isso é possível de dois modos:

É meritório (meritum) aquilo que alguém faz em conformidade com o dever para além daquilo a que pode ser obrigado de acordo com a lei; [...] aquilo que faz a menos em comparação com o que a lei exige é demérito (demeritum) moral. O efeito jurídico de um delito é a pena (poena). ${ }^{49}$

Quem faz mais do que precisa é, consequentemente, elogiado; quem faz menos, é censurado. Para Kant, o adjetivo "moral" não tem o significado que hoje vinculamos a essa expressão, isto é, como "correspondente à moral", em oposição a "correspondente ao Direito", por exemplo. O adjetivo "moral" em Kant designa na verdade o sistema de regras de comportamento no qual a ação questionada é avaliada. Isso corresponde ao que (no sentido atual) se consideram regras morais, como também se refere às regras jurídicas ${ }^{50}$. A censura encontra

47 KANT, AA VI, p. 227.

48 Sobre a história do conceito de imputação, veja-se o trabalho detalhado de HRUSCHKA, Zurechnung als Operationalisierung von Verantwortung, p. 17-27.

49 KANT, AA VI, p. 227. NT: A passagem original de Kant diz: "Der rechtliche Effekt einer Verschuldung ist die Strafe (poena)". Apesar de traduzida por José Lamego como "delito", em Kant o conceito "Verschuldung" adquire o significado de "fazer-se criminalmente responsável por um ato punível". É o que se extrai da definição trazida na página 224 da Metafísica dos costumes: "Eine unvorsetzliche Übertretung, die gleichwohl zugerechnet werden kann, heißt bloße Verschuldung (culpa). Eine vorsetzliche (d.i. diejenige, welche mit dem Bewußtsein, daß sie Übertretung sei, verbunden ist) heißt Verbrechen (dolus)".

50 O oposto de "moral" para Kant é "pragmático" ou "técnico". Tais regras pragmáticas são imperativos de prudência que mostram quais ações devem ser realizadas para atingir um determinado objetivo - veja-se, a respeito, igualmente, BYRD/HRUSCHKA, Kant's Doctrine of Right, p. $3 \mathrm{~s}$. 
expressão na pena. Assim, não somente o juízo de imputação penal possui o significado de uma censura, como também essa censura é vinculada à pena e à execução da pena - justamente porque a punição apenas pode ser fundamentada pela via de um juízo de imputação.

\section{Sexta tese: Se 0 Estado ameaça determinado comportamento com a punição, ele também é obrigado de forma absoluta a aplicar a lei penal}

A seguinte passagem é amplamente referida como prova de que Kant defende uma teoria retributiva, segundo a qual a punição seria um fim em si mesmo, independentemente de qualquer consideração teleológica.

A pena judicial (poena forensis), distinta da pena natural (poena naturalis), mediante a qual o agravo se pune a si mesmo e que não é, de modo algum, tomada em conta pelo legislador, não pode nunca servir simplesmente de meio para fomentar um outro bem, seja em favor do próprio delinquente seja da sociedade civil, mas há-de ser-lhe sempre infligida somente porque cometeu um crime; porque o homem não pode nunca ser tratado simplesmente como meio para os propósitos de outrem e confundido com os objetos do direito real ${ }^{51}$, tratamento relativamente ao qual o protege a sua personalidade inata, se bem que possa, bem entendido, ser condenado a perder a personalidade civil. Deve ser considerado passível de punição mesmo antes de se poder pensar em retirar desta punição qualquer vantagem para si próprio ou para os seus concidadãos. A lei penal é um imperativo categórico e mal daquele que rasteja pelas sinuosidades do eudemonismo para encontrar algo que o exima da pena ou mesmo de parte dela mediante a vantagem que promete. ${ }^{52}$

Kant designa a lei penal como imperativo categórico. Imperativos categóricos são incondicionais e desvinculados de fins específicos, enquanto outros imperativos ("técnicos") fornecem meios para a persecução de determinado objetivo e, portanto, são vinculantes sob a condição hipótetica de que este objetivo será buscado $^{53}$.

Kant se opõe à ideia de que a punição de um ato deva depender de outros objetivos. A sua referência à manifestação de Caifás no processo contra Jesus,

51 NT: A expressão "direito real" da tradução portuguesa se refere à palavra "Sachenrecht", isto é, o "direito das coisas", segundo se convencionou chamar no Brasil.

52 KANT, AA VI, p. 331.

53 Veja-se KANT, AAVI, p. 222 e s. 
de que "é melhor morrer um homem a perecer todo um povo"54, estabelece claramente que um inocente não deve estatuir qualquer exemplo $\mathrm{o}^{55}$. No entanto, a situação pode ser igualmente imaginada de maneira inversa, isto é, um culpado sendo liberado por alguma razão qualquer ${ }^{56}$. Isso tampouco é aceitável, pois:

a justiça deixa de existir como tal quando dela se abre mão por qualquer preço que seja $a^{57}$.

Kant argumenta decididamente contra o ditado de Seneca: "Nemo prudens punit quia peccatum est, sed ne peccetur" ${ }^{\prime 58}$, e assim vincula à discussão da época acerca da pena e do Direito Penal um ponto que se contrapõe, por exemplo, ao ponto defendido por Beccaria. Enquanto Beccaria considerava que o fim da pena não poderia ser qualquer outro que não o de "impedir que o culpado inflija a seus cocidadãos novos males, e dissuadir outros de realizar ações semelhantes" tal fundamentação da pena, para Kant, coloca as coisas de "ponta-cabeça". Ao invés disso,

a justiça penal (iustitia punitiva), dado que o argumento da punibilidade é um argumento moral (quia peccatum est), tem que distinguir-se do argumento da prudência penal, uma vez que esta é meramente pragmática (ne peaetur) e se funda na experiência daquilo que é mais eficaz para prevenir o crime ${ }^{60}$.

O fundamento da pena antecede toda consideração de utilidade e erige-se da lei em si. Uma vez que o legislador promulgou uma lei penal, e uma vez que o criminoso violou essa lei, a pena precisa ser aplicada ${ }^{61}$. A prudência pragmática diante da pena simplesmente não constitui um argumento de natureza jurídica. Isso não significa que a prudência pragmática precisa ser deixada totalmente de

54 KANT, AA VI, p. 332, citação de João, 11,50.

55 Contudo, esta seria a consequência - extrema - de um utilitarismo rigorosamente implementado - cf. o exemplo discutido por SMART, Utilitarianism, p. 69 ss.: 0 xerife de uma pequena cidade se depara com a opção de entregar um homem inocente à justiça de linchamento ou arriscar a ocorrência de tumultos, nos quais centenas perderão a vida. A crítica de WILLIAMS, Utilitarianism, p. 93 ss., é dirigida principalmente contra esta consequência do utilitarismo.

Kant dá o exemplo do criminoso que é exonerado da pena de morte porque se disponibiliza para experiências médicas perigosas.

61 Com maiores detalhes, HRUSCHKA, ob. cit. (nota 6), p. 24 e ss. 
lado. Ela pode, por exemplo, ser considerada para fins de execução da pena ${ }^{62}$. Nesse caso, quem está cumprindo uma pena legítima não será utilizado tampouco como "simples" meio para a persecução de outros objetivos. O fundamento jurídico da pena é exclusivamente a prática de um crime $^{63}$. Em dicção atual, isto não é nada mais do que o princípio da legalidade ${ }^{64}$.

Contudo, nessa hipótese, a aplicação da lei parece se tornar uma mera formalidade, sem maior sentido, caso a comunidade estatal venha a se dissolver. E, assim, surge o conhecido "exemplo da ilha" de Kant como paradigma para a compreensão de que, em última análise, se trata de uma punição que é livre de qualquer objetivo e que, portanto, expressa uma pena sem sentido. Nas palavras de Kant:

Mesmo que se dissolvesse a sociedade civil com o assentimento de todos os seus membros (por exemplo, se um povo que habita uma ilha decidisse separar-se e espalhar-se pelo mundo inteiro), teria antes que ser executado o último assassino que se encontrasse na prisão, para que a cada um aconteça aquilo que os seus atos merecem e o sangue derramado não seja da responsabilidade do povo que não exigiu este castigo: pois pode ser considerado como cúmplice desta violação pública da justiça. ${ }^{65}$

Como a completa dissolução de um Estado se trata, certamente, de um caso improvável, um potencial criminoso dificilmente poderia depositar esperanças nisso, de maneira que a autoridade da lei não seria colocada em questão em face dessa simples possibilidade. Embora não seja infrequente, tal consideração erra o ponto do "exemplo da ilha", pois, visto que a terra é redonda, o morador da ilha, após a dissolução de seu Estado, forçosamente iria ter contato com outras pessoas $^{66}$. Nesse caso, a fundação de um Estado resultaria, novamente, como postulado da razão. Mas como se envolver em um estado de juridicidade com outras pessoas, as quais, em outra ocasião, já demonstraram que não cumprem a lei ${ }^{67}$ ?

62 Nessa linha, FEUERBACH, Anti-Hobbes, p. 226 (nota de rodapé): "A afirmação de Sêneca, tão frequentemente utilizada pelos penalistas filosóficos [...] é, portanto, verdadeira e falsa em diferentes aspectos. É verdadeira, quando se refere à finalidade da execução da pena; é falsa, quando se refere à razão jurídica da mesma".

64 Cf. BYRD/HRUSCHKA, JZ 2007, p. 960 ss.

65 KANT, AA VI, p. 333.

66 Cf. KANT, AA VI, p. 262: "[...] pois que, se a terra fosse uma superfície plana infinita, os homens poderiam disseminar-se de tal jeito que não chegariam de modo algum a uma comunidade entre si, e, portanto, esta não seria uma consequência necessária da sua existência sobre a terra". Em detalhes sobre isso, HURSCHKA, Kant und der Rechtsstaat, p. 48-88 (especialmente, p. 67 ss.).

67 ALTENHAIN, ob. cit. (nota 6), p. 12, compreende o exemplo da ilha do mesmo modo. 
Com outras palavras: os moradores da ilha mentiram; por qual motivo se deveria confiar neles novamente?

Pode-se esclarecer essa argumentação à luz da pergunta sobre se poder-se-ia querer "uma lei geral para mentir", com a qual Kant debateu na fundamentação da primeira variação do imperativo categórico ${ }^{68}$. Não se poderia, simplesmente, querer uma lei geral para poder mentir,

porque conforme tal lei não haveria realmente promessa alguma, pois seria em vão fingir a minha vontade em relação às minhas ações futuras a outros, que não acreditariam nessa pretensão, ou, se o fizessem precipitadamente, me pagariam na mesma moeda, dado que a minha máxima, assim que fosse feita uma lei geral, teria que destruir a si mesma ${ }^{69}$.

Uma lei que não é aplicada não é nada mais do que uma mentira do legislador. Uma vez que, segundo Kant, o legislador nada mais é do que a totalidade dos membros da sociedade, essa mentira é censurada, do mesmo modo que a "culpa de sangue" ("Blutschuld"), a cada um dos membros dessa coletividade ${ }^{70}$ como se dá em relação a toda culpa coletiva ${ }^{71}$. Portanto, por meio do exemplo da ilha, Kant quer deixar claro que, por considerações principiológicas, não se pode colocar o Direito em causa. A consequência de uma renúncia à execução do julgamento penal no exemplo da ilha seria o completo abandono do Direito - para Kant, uma alternativa inaceitável.

\section{Sétima tese: Uma exceção cabe apenas se, de modo evidente, a coação cominada não puder preencher 0 seu objetivo}

Para o caso do estado de necessidade exculpante (§ 35 StGB [Strafgesetzbuch, Código Penal alemão]), Kant aceitava uma exceção ao dever de punir o ilícito. Kant exemplificou essa exceção por meio da clássica "tábua de Carnéades"72. Mesmo em caso do mais elevado perigo de vida, não se pode dar o direito a al-

KANT, Grundlegung zur Metaphysik der Sitten, p. 402: "Não devo jamais proceder de outra maneira, que não a de poder querer também que a minha máxima se constitua em uma lei geral".

69 KANT, AA VI, p. 403.

70 KANT, AA VI, p. 333.

71 HURSCHKA, salientou que, de acordo com o uso da época, a expressão "culpa homicida" ("Blutschuld") de forma alguma significava algo místico, sendo simplesmente algo "dito daqueles que isentam da punição um criminoso que no entanto merece a pena de morte" - veja-se HURSCHKA, ZStW 122, p. 501 s. Isso pode ser encontrado em WALCH, Philosophisches Lexikon I, p. 454. 
guém de, para salvar a própria vida, matar outra pessoa ${ }^{73}$, pois, para o reconhecimento do estado de necessidade - necessariamente para todas as pessoas que se encontram em perigo de vida -, haveria coerção jurídica contra coerção jurídica, o que é inassociável com uma relação jurídica recíproca entre pessoas livres ${ }^{74}$. No entanto, o autor nota que a determinação de condutas por meio do Direito fracassa em situações dessa espécie.

Não pode, com efeito, haver uma lei penal que imponha a morte a quem, num naufrágio, correndo com outro um risco de morte similar, o empurre da prancha onde este se tinha posto a salvo, para se salvar a si próprio. Pois que a pena cominada pela lei não poderia ser maior do que a perda da vida sofrida pelo primeiro. Em tal caso, uma tal lei não pode ter o efeito visado; pois a ameaça de um mal, que ainda é incerto (a ameaça de morte por efeito de sentença judicial), não pode prevalecer sobre o medo de um mal que é certo (quer dizer, morrer afogado). ${ }^{75}$

O tratamento, por Kant, do estado de necessidade como "não punível (impunibile)"76 significa que o agente em estado de necessidade não pode ser chamado à responsabilidade por seu ato ilícito, e que não poderá ser imputada a ele a consequência jurídica para sua ação proibida ${ }^{77}$. Se a afirmação de que a retribuição é um fim em si mesma fosse correta, então essa exceção não poderia ser explicada, pois a perda da vida da vítima é tão inquestionável quanto o fato de a sua morte ser o resultado de um ato ilícito. O objetivo do empreendimento do Direito Penal como um todo já não consiste, também para Kant, na realização de uma qualquer justiça transcendental ${ }^{78}$, mas sim trata-se da questão de como o Direito (Penal) dirige comportamentos e, desse modo, pode proteger a liberdade.

73 Veja KANT, AA VI, p. 236: "[...] e, no entanto, não pode haver necessidade que torne lícito aquilo que é desconforme ao Direito".

74 Cf. KÜPER, Immanuel Kant und das Brett des Karneades, p. 6 e ss.

75 KANT, AA VI, p. 235.

76 KANT, AA VI, p. 236.

77 Cf. HURSCHKA, GA 1991, p. 8 ss.; crítico, KÜPER, ob. cit. (nota 74), p. 48 e ss.

78 Note-se: "justiça transcendental" e não "justiça metafísica". A justiça não tem nada a ver com metafísica, a menos que se defenda uma doutrina natural do direito extremada, segundo a qual todas as coisas trazem dentro de si seu padrão de justiça, de maneira que "justo" e "injusto" não passariam de propriedades empíricas. Todavia, Kant conhece muito bem a diferença entre o ser e o dever-ser, de modo que se pode considerar pura tolice essa acusação contra a sua teoria da pena. 


\section{Oitava tese: A oposição entre teorias retributivas e preventivas é um problema aparente}

A partir das considerações anteriores, comprova-se que a disputa entre as teorias preventivas e retributivas é um falso problema - ao menos no que se refere a Kant. Toda norma jurídica, não apenas uma lei penal, deve influenciar o comportamento do seu destinatário e, portanto, funciona preventivamente. Normas jurídicas precisam, contudo, também ser aplicadas - ou elas não são Direito algum. Por meio da aplicação da pena, o Estado demonstra que "fala sério" e que também no futuro irá reagir aos crimes de modo correspondente. Se um Estado de Direito é a essência de uma ordem jurídica, então ele deixa de ser um Estado de Direito se não aplicar as suas leis.

Portanto, através da lei penal e de sua execução devem ser evitados crimes futuros, na medida em que aos potenciais autores será evidenciada a imposição de um mal, o qual também incidirá para eles, se for necessário. Nesse sentido, não se pode ter prevenção sem retribuição ${ }^{79}$. Prevenção, contudo, é apenas um efeito colateral incontrolável pelo Direito Penal e pela punição, porque os impulsos, a partir dos quais cada qual atua, apenas podem ser analisados de modo teorético, já que não podem ser constatados na prática. Talvez se demonstre precisamente nisso o caráter liberal do Estado de Direito: no fato de que ele renuncia à pretensão de ser uma casa de correção moral.

\section{Nona tese: A medida da pena se orienta pelo ilícito e neste aspecto a culpabilidade é contingente}

Em relação à medida da pena, Kant defende um rigoroso princípio taliônico: Mas que espécie e que grau de punição adopta a justiça pública como princípio e como medida? Não pode ser outro senão o da igualdade [...] Só a lei de retribuição (ius talionis) [...] pode indicar de maneira precisa a qualidade e a quantidade da pena. ${ }^{80}$

Para o assassino, portanto, apenas pode se dar a pena de morte; para o autor do roubo e do furto, o trabalho forçado ${ }^{81}$. Mas o último exemplo já não se aplica de modo exato, e Kant também o vê nos casos do estupro ou do abuso sexual infantil. Tais delitos não permitem "nenhuma retribuição", "porque tais punições são em si mesmas impossíveis ou constituem por si só um crime punível 
contra a humanidade em geral"82. É duvidoso se um princípio taliônico tão estrito deriva realmente dos princípios da Doutrina do Direito kantiana ou se não se caberia - pura e simplesmente - tirar a conclusão de que o grau de punição deve corresponder à extensão do injusto e da culpabilidade.

A preocupação de Kant é, sobretudo, a de colocar fim na arbitrariedade do então dominante arbítrio judicial na práxis da dosimetria da pena ${ }^{83}$.

Impor arbitrariamente penas para estes crimes é literalmente contrário ao conceito de uma justiça a penal. Só que o criminoso não pode queixar-se de que se comete contra ele uma injustiça quando faz recair sobre si mesmo a sua má acção e lhe acontece aquilo que infligiu a outras pessoas, mesmo que não seja segundo a letra, mas sim segundo o espírito da lei penal. ${ }^{84}$

Tal espécie de dosimetria da pena, feita "segundo o espírito da lei penal", considera que o criminoso de certa forma se excluiu da participação na sociedade civil através do crime que praticou, na medida em que ele desatendeu as leis da liberdade. Por meio da punição é precisamente isso o que ele irá receber. A pena é uma forma de exclusão da participação integral por meio de uma perda de direitos, a qual, de forma mais expressiva, se manifesta pela pena privativa de liberdade. Mas também uma pena pecuniária se apresenta como alternativa, porque assim é afetado o fundamento econômico para a participação na sociedade. A perda na liberdade ou propriedade precisa ser adequada à gravidade do crime $^{85}$. De fato, resulta disso a "dosimetria da pena proporcional ao fato" 86 como pressuposto para que a pena se apresente como justa, e não apenas como vingança arbitrária.

\section{Conclusão}

Para Kant, portanto, a retribuição não é, de modo algum, um objetivo em si, mas sim uma forma de coerção jurídica para a execução do Direito. Ou, nas palavras de Hruschka: "O conceito de um poder supremo [...] e de uma justiça penal [...] implicam-se um ao outro" ${ }^{87}$. Não apenas o Estado de Direito é uma

KANT, AA VI, p. 363, acerca da castração.

83 Cf. SCHAFFSTEIN, Die allgemeinen Lehren vom Verbrechen in ihrer Entwicklung durch die Wissenschaft des Gemeinen Strafrechts, p. 39 ss.

84 KANT, AA VI, p. 363.

85 RIPSTEIN, ob. cit. (nota 23), p. 246.

86 Nesse sentido a publicação, com o mesmo nome, de HÖRNLE, Tatproportionale Strafzumessung.

87 HRUSCHKA, ob. cit. (nota 6), p. 32. 
condição necessária para a justiça penal, mas a justiça penal é também um pressuposto necessário para o Estado de Direito.

Talvez, a disputa acerca das distintas teorias dos fins da pena tangencie o fato de que se exija muito do conceito da pena, ao invés de se distinguir que:

A pena é um mal por definição, o qual será aplicado para comportamentos ilícitos e culpáveis (e nessa medida se trata, pois, de retribuição). A pena possui um significado (comunicativo) de censura. Sua execução serve ao fim da prevenção. Todavia, isso não consiste em qualquer "teoria unificadora" no sentido comum, no qual diversos pedaços são misturados, como em uma espécie de ensopado.

\section{Referências}

AICHELE, Alexander. Was ist und wozu taugt das Brett des Karneades? Wesen und ursprünglicher Zweck des Paradigmas der europäischen Notrechtslehre. Jahrbuch für Recht und Ethik, Berlin, v. 11, p. 245-268, 2003.

ALTENHAIN, Karsten. Die Begründung der Strafe bei Kant und Feuerbach. In:

Strafrechtsprofessoren der Tübinger Juristenfakultät u.a. (Hrsg.). Gedächtnisschrift für Rolf Keller. Tübingen: Mohr Siebeck, 2003. p. 1 ss.

BECCARIA, Cesare. Ueber Verbrechen und Strafe. Trad. Glaser. Wien: [s.n.], 1851. (= Dos delitos e das penas. 2. ed. Trad. José de Faria Costa. Lisboa: Fundação Calouste Gulbenkian, 2007.)

BYRD, B. Sharon; HRUSCHKA, Joachim. Kant zu Strafe und Strafrecht im Rechtsstaat. Juristen Zeitung, [s.I.], v. 62, n. 20, p. 957-964, 2007.

BYRD, B. Sharon; HRUSCHKA, Joachim. Kant's Doctrine of Right: a commentary. Cambridge: Cambridge University Press, 2010.

FEUERBACH, Paul Johann Anselm Ritter von. Anti-Hobbes oder über die Grenzen der höchsten Gewalt und das Zwangsrecht der Bürger gegen den Oberherrn. Erfurt: [s.n.], 1798.

FEUERBACH, Paul Johann Anselm Ritter von. Lehrbuch des gemeinen in Deutschland gültigen peinlichen Rechts. 14. Auflage. Gießen: [s.n.], 1847.

FEUERBACH, Paul Johann Anselm Ritter von. Revision der Grundsätze und Grundbegriffe des positiven peinlichen Rechts. Erster Theil. Erfurt: [s.n.], 1799.

FRISCH, Wolfgang. Zum Zweck der Strafandrohung. In: HEFENDEHL, Roland; HÖRNLE, Tatjana; GRECO, Luís (Hrsg.). Streitbare Strafrechtswissenschaft. Festschrift für Bernd 
Schünemann zum 70. Geburtstag am 1. November 2014. Berlin: Duncker \& Humblot, 2014. p. 55-68.

GRECO, Luís. Lebendiges und Totes in Feuerbachs Straftheorie. Berlin: Duncker \& Humblot, 2009.

HAAS, Volker. Strafbegriff, Staatsverständnis und Prozessstruktur. Tübingen: Mohr Siebeck, 2008.

HASSEMER, Winfried. Theorie und Soziologie des Verbrechens. Frankfurt am Main: Athenäum-Verlag, 1973.

HÖRNLE, Tatjana. Tatproportionale Strafzumessung. Duncker \& Humblot, 1999.

HRUSCHKA, Joachim. Das Erlaubnisgesetz der praktischen vernunft und der ursprüngliche Erwerb von Stücken des Erdbodens. In: HRUSCHKA, Joachim. Kant und der Rechtsstaat. Freiburg im Breisgau: Alber, 2015. p. 48-88.

HRUSCHKA, Joachim. Die "Verabschiedung" Kants durch Ulrich Klug im Jahre 1968: Einige Korrekturen. Zeitschrift für die Gesamte Strafrechtswissenschaft, Berlin, v. 122, p. 493-503, 2010. DOI: 10.1515/zstw.2010.493.

HRUSCHKA, Joachim. Drei Vorschläge Kants zur Reform des Strafrechts. In: JAHN, Matthias (Hrsg.). Strafrechtspraxis und Reform: Festschrift für Heinz Stöckel zum 70. Geburtstag. Berlin: Duncker \& Humblot, 2010. p. 77-92.

HRUSCHKA, Joachim. Kant, Feuerbach und die Grundlagen des Strafrechts. In: PAEFFGEN, Hans-Ulrich (Hrsg.). Strafrechtswissenschaft als Analyse und Konstruktion. Festschrift für Ingeborg Puppe. Berlin: Duncker \& Humblot, 2001. p. 17-37.

HRUSCHKA, Joachim. Rechtfertigungs- und Entschuldigungsgründe: Das Brett des Karneades bei Gentz und Kant. Goltdammer's Archiv für Strafrecht, [s.I.], p. 1-10, 1991. (= Causas de justificación y causa de exculpación: la tabla de Carnéades en Gentz y en Kant. Trad. Ricardo Robles Planas. In: HRUSCHKA, Joachim. Imputación y derecho penal. Estudios sobre la teoría de la imputación. 2. ed. Buenos Aires: B de F, 2009. p. 103-118.)

HRUSCHKA, Joachim. Zurechnung seit Pufendorf. Insbesondere die Unterscheidungen des 18. Jahrhunderts. In: KAUFMANN, Matthias; RENZIKOWSKI, Joachim (Hrsg.). Zurechnung als Operationalisierung von Verantwortung. Frankfurt am Main: Lang, 2004. p. 17-27.

HRUSCHKA, Joachim; JOERDEN, Jan. Supererogation: Vom deontologischen Sechseck zum deontologischen Zehneck. Archiv für Rechts- und Sozialphilosophie, [s.I.], v. 73, p. 93-123, 1987. 
JAKOBS, Günther. Strafrecht. Allgemeiner Teil. Die Grundlagen und die Zurechnungslehre Lehrbuch. 2. Auflage. Berlin: Walter de Gruyter Verlag, 1991. (= Derecho penal. Parte general. Fundamentos y teoría de la imputación. 2. ed. Trad. Joaquín Cuello Contreras e José Luis Serrano González de Murillo. Madrid: Marcial Pons, 1997.)

JESCHECK, Hans-Heinrich; WEIGEND, Thomas. Lehrbuch des Strafrechts. 5. ed. Berlin: Dunckler \& Humblot, 1996. (= Tratado de derecho penal: parte general. 5. ed. Trad. Miguel Olmedo Cardenete. Granada: Comares, 2003.)

JOECKS, Wolfgang. Joecks. Einleitung. In: JOECKS, Wolfgang (Hrsg.). Münchener Kommentar zum Strafgesetzbuch. 2. Auflage. München: C.H. Beck, v. 1, 2011.

KANT, Immanuel. Grundlegung zur Metaphysik der Sitten (2. Auflage, 1785). In: Königlich-Preussische Akademie der Wissenschaften (Hrsg.). Kants gesammelte Schriften. Erste Abteilung. Berlin: [s.n.], v. 4, 1911. p. 385-463. (= Fundamentação da metafísica dos costumes. Trad. Paulo Quintela. Lisboa: Edições 70, 2007.)

KANT, Immanuel. Kritik der reinen Vernunft (2. Auflage, 1787). In: KöniglichPreussische Akademie der Wissenschaften (Hrsg.). Kants gesammelte Schriften. Erste Abteilung. Berlin: [s.n.], v. 3, 1911. (= Crítica da razão pura. 5. ed. Trad. Manuela Pinto dos Santos e Alexandre Fradique Morujão. Lisboa: Calouste Gulbenkian, 2001.)

KANT, Immanuel. Metaphysik der Sitten (2. Auflage, 1798). In: Königlich-Preussische Akademie der Wissenschaften (Hrsg.). Kants gesammelte Schriften. Erste Abteilung. Berlin: [s.n.], v. 6, 1907. p. 203-493. (= A metafísica dos costumes. 3. ed. Trad. José Lamego. Lisboa: Calouste Gulbenkian, 2017.)

KLUG, Ulrich. Abschied von Kant und Hegel. In: BAUMANN, Jürgen (Hrsg.). Programm für ein neues Strafgesetzbuch: Der Alternativentwurf der Strafrechtslehrer. Frankfurt am Main: Fischer-Bücherei, 1968. p. 36-41.

KÜHL, Kristian. Die ethisch-moralischen Grundlagen des Strafrechts. Zeitschrift für die Gesamte Strafrechtswissenschaft, Berlin, v. 116, p. 870-890, 2004. DOI: 10.1515/ zstw.2004.116.4.870.

KÜPER, Wilfried. Immanuel Kant und das Brett des Karneades: das zweideutige Notrecht in Kants Rechtslehre. Heidelberg, C.F. Müller, 1999.

MARX, Michael. Zur Definition des Begriffs "Rechtsgut". Prolegomena einer materialen Verbrechenslehre, Berlin/Bonn/München: Heymann, 1972.

PAWLIK, Michael. Person, Subjekt, Bürger. Berlin: Duncker \& Humblot, 2004.

RENZIKOWSKI, Joachim. Notstand und Notwehr. Berlin: Duncker \& Humblot, 1994. 
RIPSTEIN, Arthur. Hindering a Hindrance to Freedom. Jahrbuch für Recht und Ethik, Berlin, v. 16, p. 227-250, 2008.

ROXIN, Claus. Strafrecht: Allgemeiner Teil. Grundlagen, der Aufbau der Verbrechenslehre. 4. ed. München: Beck, v. I, 2006. (Há tradução para o espanhol da segunda edição, de Diego-Manuel Luzón Peña, Miguel Díaz y García Conlledo e Javier de Vicente Remesal. Derecho penal - Parte general: fundamentos. La estructura de la teoría del delito. Madrid: Civitas, 1997.)

SCHAFFSTEIN, Friedrich. Die allgemeinen Lehren vom Verbrechen in ihrer Entwicklung durch die Wissenschaft des Gemeinen Strafrechts. Berlin: Julius Springer, 1930.

SCHÜNEMANN, Bernd. Aporien der Straftheorie in Philosophie und Literatur Gedanken zu Immanuel von Kant und Heinrich von Kleist. In: PRITTWITZ, Cornelius (Hrsg.). Festschrift für Klaus Lüderssen zum 70. Geburtstag am 2. Mai 2002. BadenBaden: Nomos Verlag, 2002. p. 327-344. (= Aporías de la teoría de la pena en la filosofía: pensamientos sobre Immanuel Kant. Trad. José Milton Peralta. InDret Penal, Barcelona, n. 2, 2008. Disponível em: https://indret.com/wp-content/themes/indret/ pdf/531.pdf. Acesso em: 21 fev. 2022.)

SMART, John Jamieson Carswell. An outline of a system of utilitarian ethics. In: SMART, John Jamieson Carswell; WILLIAMS, Bernard (Org.). Utilitarianism: for and against. Cambridge, Cambridge University Press, 1973. p. 3-74.

STRATENWERTH, Günter. Was leistet die Lehre von den Strafzwecken? Berlin/New York: de Gruyter, 1995. (= ¿Qué aporta la teoría de los fines de la pena? Trad. Marcelo Sancinetti. Bogotá: Universidad del Externado de Colombia, 1995.)

VON HIRSCH, Andrew. Warum soll die Strafsanktion existieren? - Tadel und Prävention als Elemete einer Rechtfertigung. In: VON HIRSCH, Andrew; NEUMANN, Ulfrid; SEELMANN, Kurt (Hrsg.). Strafe - Warum? Baden-Baden: Nomos, 2011. p. 43-68.

WALCH, Johann Georg. Philosophisches Lexikon. 4. Auflage. Leipzig: [s.n.], v. I, 1968 (1775).

WILLIAMS, Bernard. A critique of utilitarianism. In: SMART, John Jamieson Carswell; WILLIAMS, Bernard (Org.). Utilitarianism: for and against. Cambridge, Cambridge University Press, 1973. p. 85-150.

\section{Conflito de interesses}

O autor declara a ausência de conflito de interesses na produção do presente trabalho. 
Sobre 0 autor:

Joachim Renzikowski | E-mail: joachim.renzikowski@jura.uni-halle.de

Doutor em Direito (Uni-Tübingen/Alemanha). Professor Titular de Direito Penal, Teoria Jurídica e Filosofia Jurídica (Universidade de Halle-Wittenberg/Alemanha).

Recebimento: 21.02.2022

Aprovação: 22.02.2022

Artigo convidado 


\section{Evitação do dolo por dirigentes de empresas nos delitos relacionados à atividade empresarial*}

\section{Dolus avoidance by managers in corporate crimes}

\section{Thomas Rönnau}

\section{Christian Becker}

Resumo: Na maioria dos delitos relacionados a empresas, os dirigentes não estão diretamente envolvidos na realização do tipo penal. Não obstante, eles podem ser responsabilizados por omissão, quando deixarem de tomar medidas necessárias para impedir a prática dos crimes cometidos por seus subordinados. Para isso, é preciso que tenham atuado com dolo, ao menos eventual. Neste artigo, os autores examinam os pressupostos de imputação subjetiva nos crimes omissivos impróprios praticados por dirigentes de empresas em relação aos fatos realizados por seus subordinados. Para tanto, após examinar os pressupostos jurídico-materiais do dolo, destacam especialmente as exigências para a sua determinação processual. Ao fim, descrevem a responsabilidade contraordenacional das pessoas jurídicas pela omissão no controle de atos ilícitos dos empregados, uma responsabilidade que independe do dolo dos dirigentes.

Palavras-chave: criminalidade de empresa; responsabilidade penal de diretores; crimes omissivos impróprios; dolo; sistemas de conformidade.

Abstract: In most of the corporate crimes, the managers are not directly involved in carrying out the criminal offense. However, they can be held responsible for omission, when they fail to take the necessary measures to prevent the criminal conducts committed by their subordinates. To establish that responsibility, they must have acted with criminal intent (dolus directus) or at least with dolus eventualis. In this article, the authors examine the conditions of mens rea in criminal omissions by company directors regarding facts carried out by their subordinates. After examining the legal definition of criminal intent, they especially highlight the requirements for its procedural determination. Finally, they

\footnotetext{
* Publicação original: RÖNNAU, Thomas; BECKER, Christian. Vorsatzvermeidung durch Unternehmensleiter bei betriebsbezogenen Straftaten. Neue Zeitschrift für Strafrecht, [s.I.], p. 569-575, 2016. Tradução de Marcelo Costenaro Cavali.
} 
describe the administrative liability of legal entities for the failure to control illegal acts of employees, a responsibility that does not depend on the intent of the managers.

Keywords: corporate crimes; criminal liability of corporate managers; criminal omissions; dolus; compliance programs.

Sumário: Introdução; 10 s pressupostos jurídico-materiais do conceito de dolo; 1.1 Fundamentos; 1.2 Dolo como fato psicológico (interno); 2 A determinação processual do dolo; 2.1 Ponto de partida; 2.20 elemento cognitivo do dolo; 2.30 componente volitivo; 3 Responsabilidade de acordo com 0 \$130 0WiG; Conclusão; Referências.

\section{Introdução}

Ocorrendo o cometimento de delitos em uma empresa, que se encontrem em conexão interna com sua atividade empresarial ou seu tipo de empreendimento (os chamados delitos relacionados à empresa) ${ }^{1}$, não existe, na maioria das vezes, um comportamento típico imediato por parte dos membros da direção da empresa ou, de todo modo, não é possível prová-lo. Assim ocorre, por exemplo, com os pagamentos de propinas, um fenômeno tipicamente levado a cabo, em empresas organizadas sob a forma de sociedade por ações, no nível de gerência intermediário².

No curso do chamado "caso de liberação de gases poluentes da VW", cujos inquéritos penais ainda estão no início ${ }^{3}$, os membros do conselho de administração não estavam diretamente envolvidos, até onde se sabe, no desenvolvimento do software que diminuía temporariamente os níveis de emissão de poluentes durante a realização dos testes regulatórios ${ }^{4}$. Se, em tais condições, é possível uma responsabilidade penal para além do nível hierárquico diretamente envolvido (empregados do departamento de vendas, engenheiros, etc.), de modo a atingir também os gestores da empresa, é algo que dependerá decisivamente da medida do conhecimento dos dirigentes sobre os comportamentos delitivos de seus subordinados $^{5}$. Se esse for o caso, não se considera apenas a participação ativa no

1 Para o conceito de delitos relacionados à empresa, cf. BGHSt 57, 42 = NJW 2012, 1237 (1238); para aprofundamento, ver BÜLTE, Vorgesetztenverantwortlichkeit im Strafrecht, p. 154 e ss.; SCHALL, FS-Kühl, p. 426 ss., com outras referências.

2 RÖNNAU, FS-Tiedemann, p. 713.

3 Primeiras reflexões sobre essa questão em ISFEN, JA 2016, p. 1 s., concluindo que uma punibilidade por estelionato poderia ser "considerada"; sobre a possível sonegação fiscal relacionada com a concessão de isenções fiscais por meio da declaração incorreta da classe de poluentes, cf. HEß, wistra 2016, p. 212 e ss.

5 WELLER, ZGR 45, p. 386, que descreve o conhecimento do acusado como o "ponto central de toda pena". 
delito relacionado à empresa dos empregados em questão, mas também, independentemente de uma ação comissiva, da punibilidade por omissão, por força, ao menos em princípio, da predominantemente reconhecida responsabilidade dos dirigentes de empresa por omissão (Geschäftsherrenhaftung) ${ }^{7}$.

Neste contexto, pode-se deparar com o fenômeno da chamada "cegueira deliberada" ${ }^{8}$, quando o desconhecimento do dirigente empresarial não tiver por base comportamentos conspiratórios dos empregados criminosos, mas, sim, o fato de os membros dos escalões mais altos não quererem tomar conhecimento de processos criminosos evidentes em curso na empresa, ignorando, portanto, os sinais e bloqueando as respectivas informações ("bad news doesn't flow upstream" $\left.^{\prime \prime}\right)^{9}$. Mesmo que seja possível imputar o conhecimento à empresa, sob certas condições ${ }^{10}$, no caso de ignorância contrária ao dever, a exigência de dolo inviabiliza, geralmente, uma fundamentação da responsabilidade penal individual. Esse resultado é particularmente questionável do ponto de vista político-criminal ali onde o dirigente, em um primeiro momento, formula metas que claramente não são atingíveis sem violação à lei, para, em um segundo momento, alegar ignorância dos crimes quando eles são efetivamente cometidos. Pense-se, por exemplo (no âmbito do direito das contraordenações), nas regulamentações sobre quantidades de cargas e prazos de entrega em uma empresa de transportes, que são praticamente inviáveis de serem atendidos sem sobrecarga ou sem a desconsideração dos períodos de descanso prescritos para os empregados ${ }^{11}$.

Sobre os diferentes tipos de participação ativa, cf. ROTSCH, Criminal Compliance, $\S 4 \mathrm{~nm}$. 4 e ss.: também ACHENBACH, Handbuch Wirtschaftsstrafecht, I 3, nm. 24 e ss.

7 Visão geral em ROTSCH, Handbuch Wirtschaftsstrafecht, I 4 nm. 73 e s.; KK-OwiG-Rogall, § 130 nm. 2, cada qual com ulteriores indicações sobre o estado da discussão.

8 Sobre o contexto do Direito Penal Econômico, SCHEMMEL/KIRCH-HEIM, CCZ 1, p. 96 e s.; a respeito do Direito Penal Internacional, no âmbito do qual a cegueira deliberada desempenha um papel para a responsabilidade penal por crimes contra a humanidade, nos termos do art. 7 do Estatuto da CCI, cf. AMBOS, Internationales Strafrecht, $\S 7$, nm. 198; BÜLTE, ob. cit. (nota 1), p. 566 e ss.; sobre o Direito norte-americano, cf. LUBAN, Georgetown Law Journal 87, p. 957 e ss., que fala principalmente de "ignorância deliberada"; MARCUS, Yale Law Journal 102, p. 2231 e ss., cada qual com ulteriores indicações sobre o estado da discussão.

$9 \quad$ LUBAN, ob. cit. (nota 8), p. 958.

10 BUCK-HEEB, Corporate Compliance, §2 nm. 23 e ss.; sobre a imputação do conhecimento no âmbito empresarial, cf. recentemente WELLER, ob. cit. (nota 5), p. 396 ess.; completo, cf. SPINDLER, Unternehmensorganisationspflichten, p. 610 ss. e p. 963 ss.

11 Punível como contraordenação de acordo com os $\S 334,69 a$ (3) nº 4 StVZO (Straßenverkehrs-Zulassungs-Ordnung, Regulamento de Licenciamento do Trânsito), §24 StVG (Straßenverkehrsgesetz, Lei de Tráfego Rodoviário) e §8 FPersG (Gesetz über das Fahrpersonal von Kraftfahrzeugen und Straßenbahnen, Lei sobre Motoristas de Automóveis e Bondes), em conjunto com o art. 6 AETR (Convenção Europeia sobre o trabalho dos empregados do setor de transportes internacionais). 
Em conexão com o "caso do escândalo do diesel da VW" - especialmente com vistas à promoção de vendas de automóveis no mercado dos EUA -, a construção de motores a diesel novos e rentáveis, mas, ao mesmo tempo, ecológicos, econômicos e poderosos, chega a ser visivelmente uma "quadratura do círculo". $\mathrm{O}$ fato de esse objetivo ter sido alcançado deveria ter deixado os dirigentes pelo menos desconfiados. Se sabiam mais sobre os meios de resolução dessa complicada equação é algo que ainda não se sabe ${ }^{12}$.

Se, porém, um desconhecimento baseado na indiferença e/ou na leviandade (culpa grave) exclui a existência do dolo é algo que não depende apenas dos pressupostos jurídico-materiais do dolo eventual (ver, a seguir, Seção 1). Pelo contrário, deve-se ter em mente especialmente as exigências para a sua determinação processual (Seção 2). Finalmente, é necessário traçar as linhas da responsabilidade contraordenacional de acordo com o §130 OWiG (Gesetz über Ordnungswidrigkeiten, Lei de Contraordenações), uma responsabilidade que independe do dolo dos dirigentes (Seção 3).

\section{0 pressupostos jurídico-materiais do conceito de dolo}

\subsection{Fundamentos}

O dolo - assim como muitos outros conceitos centrais da teoria geral do delito - não está definido em lei ${ }^{13}$. Do disposto no §16 I 1 StGB (Strafgesetzbuch, Código Penal alemão) decorre, em uma interpretação a contrario sensu, que o conhecimento das circunstâncias que pertencem ao tipo legal é um elemento necessário do dolo ${ }^{14}$. Assim, a lei nomeia como objeto do dolo, um tanto ambiguamente, as circunstâncias a serem subsumidas ao tipo legal e que são, na maioria das vezes, de natureza fática, mas que têm também, por vezes, caráter valorativo (normativo) ${ }^{15}$. Além disso, reconhece-se que existem três diferentes formas de dolo: o dolo direto, que se subdivide, de um lado, em intenção, isto é, a busca proposital da realização do fato típico como objetivo final ou intermediário, e, de outro lado, em conhecimento, o conhecimento seguro da ocorrência das circunstâncias fáticas ${ }^{16}$. Como condutas praticadas com dolo direto não estarão,

12 Compare-se a apresentação dos fatos do caso em ISFEN, ob. cit. (nota 3), p. 1 e s.

13 RISSING-VAN SAAN, FS-Geppert, p. 499.

14 LKStGB-Vogel, $\$ 15 \mathrm{~nm} .73$.

15 MüKoStGB-Joecks, §16 nm. 7 com outras referências; LKStGB-Vogel, §15 nm. 28.

16 Por todos, RÖNNAU, JuS 50, p. 677; aprofundado, SAMSON, JA 1989, p. 449 e ss. 
em regra, presentes no nosso contexto, o dolo eventual (Eventualvorsatz), muitas vezes mal compreendido como dolo condicional (bedingter Vorsatz), torna-se o centro das atenções ${ }^{17}$. Os seus pressupostos são objeto de uma contínua controvérsia, cuja importância se deve principalmente à distinção em relação à imprudência, muitas vezes impune ${ }^{18}$. Sem prejuízo de certa convergência entre as posições contrárias ${ }^{19}$, contesta-se a existência de um elemento volitivo que vá além do conhecimento no sentido do §16 I 1 StGB (o chamado elemento intelectual ou cognitivo do dolo), bem como o conteúdo e a estrutura dos respectivos componentes ${ }^{20}$. O BGH (Bundesgerichtshof, Tribunal Federal alemão) acolhe em sua jurisprudência a teoria da "aprovação em sentido jurídico" (Billigung im Rechtsinne), segundo a qual o dolo eventual está presente quando o réu

reconhece a produção do resultado típico como possível e não inteiramente remota e põe-se de acordo com isso de maneira que tem uma assunção aprovadora da realização do tipo ou, em razão do objetivo perseguido, aceita que ele ocorra, ainda que a produção do resultado seja em si mesma indesejável; há culpa consciente, por outro lado, quando o agente não está de acordo com a realização do tipo reconhecida como possível, e confia seriamente - não apenas de modo vago - que o resultado não se produzirá ${ }^{21}$.

A jurisprudência coloca-se, assim, no campo das teorias volitivas, porque, ao lado da consideração como possível da realização do tipo (como elemento cognitivo do dolo), pressupõe um elemento volitivo ao exigir a "assunção aprovadora" (billingenden Inkaufnahme) ${ }^{22}$. Isso está, de fato, em consonância com a doutrina dominante, que reconhece o dolo eventual quando o agente conta seriamente com a possibilidade de realização do tipo (elemento cognitivo) e com ele se conforma (elemento volitivo), enquanto a culpa consciente é caracterizada

17 Sobre a imprecisão do conceito de "dolo condicionado", ver ROXIN, Strafrecht AT I, §12 nm. 24.

18 SCHÜNEMANN, FS-Hirsch, p. 364: "Praticamente a fronteira mais importante do Direito Penal"; SCHROTH, FS-Widmaier, p. 779 e s.

19 FRISCH, GS-Meyer, p. 539; HASSEMER, GS-Armin Kaufmann, p. 306; também PUPPE, ZStW 103, p. 1.

20 Para uma introdução ao estado da controvérsia, cf. ROXIN, ob. cit. (nota 17), §12 nm. 21 e ss.; comprovação exaustiva em HILLENKAMP, 32 Probleme aus dem Strafrecht AT, p. 1 e ss.

21 BGHSt 36, 1 = NJW 1989, 781 (783); fundamentos em BGHSt 7, 363 = NJW 1955, 1688, com mais comentários de Karl Engisch; mais recentemente BGH NStZ 2007, 700 (701).

22 Fundamentos em BGH NJW 1955, 1688 (1690); compare-se, porém, FRISCH, ob. cit. (nota 19), p. 538 e s., que atesta que o BGH abandonou a teoria do assentimento há muito tempo. 
pelo fato de que o autor, apesar da reconhecida possibilidade de realização do delito, confia seriamente na sua não ocorrência ${ }^{23}$.

\subsection{Dolo como fato psicológico (interno)}

Para esse ponto de partida das doutrinas volitivas dominantes e que não pode ser adequadamente examinado no presente artigo ${ }^{24}$, o dolo não é afastado somente quando um dirigente de empresa não contou com a possibilidade de que crimes fossem cometidos por seus subordinados, mas, além disso, quando reconhece essa possibilidade, porém, ao fim, confia seriamente que isso não chegaria a acontecer. O dolo deve, portanto - sem prejuízo do componente normativo inerente a todo conceito jurídico -, ser compreendido como um fato psicológico, como evento interno ${ }^{25}$. Assim, deve-se rejeitar uma abordagem estritamente normativa, segundo a qual o dolo, sob determinadas condições, poderia ser considerado apesar da falta de conhecimento. Essa construção tem sido defendida na doutrina jurídico-penal sobretudo por Jakobs, que parte da teoria do dolo indireto (dolus indirectus) ${ }^{26}$ e, dessa maneira, pretende compreender os casos de "indiferença diante dos fatos" (Tatsachengleichgültigkeit) - em última análise, uma espécie de cegueira deliberada (wilful blindness) - como atos dolosos ${ }^{27}$. Com algumas limitações, encontram-se tendências similares de normativização, embora menos abrangentes, também em alguns defensores de teorias cognitivas do

23 ROXIN, ob. cit. (nota 17), §12 nm. 21 e ss., em especial nm. 27; mais informações em HILLENKAMP, ob. cit. (nota 20), p. 9 e s.; sobre a ampla identidade dessa concepção com o conceito da jurisprudência, cf. FRISCH, ob. cit. (nota 19), p. 540.

24 Lúcido, por uma concepção cognitiva do dolo, cf. FRISCH, ob. cit. (nota 19), p. 536 e sS.; FRISCH, Vorsatz und Risiko, p. 473 e ss. (e passim); PUPPE, ob. cit. (nota 19), p. 9 e ss.; NKStGB-Puppe, $\$ 15$ nm. 64 e ss.; HERZBERG, JuS 26, p. 249 e ss.; por outro lado, para uma concepção volitiva, por exemplo, SCHROTH, Vorsatz als Aneignung der unrechtskonstituierenden Merkmale, p. 115 e ss.; SCHROTH, ob. cit. (nota 18), p. 783 e ss.; SCHÜNEMANN, ob. cit. (nota 18), p. 369 e s.; GAEDE, Strafgesetzbuch, $\$ 15$ nm. 21 e ss.; em complemento, também BUNG, Wissen und Wollen im Strafrecht, p. 265 e ss.

25 Mais profundamente sobre a relação entre aspectos psicológicos e normativos, cf. ROXIN, FS-Rudolphi, p. 243 e ss.; LKStGB-Vogel, $\$ 15$ nm. 64 e ss.; GAEDE, ZStW 121, p. 262 e ss.; cético, de outro lado, sobre a relevância dos fatores psicológicos, FISCHER, StGB, $\$ 15 \mathrm{~nm}$. 9; sobre a origem da concepção psicológica em Feuerbach, JAKOBS, ZStW 114, p. 588; PUPPE, ob. cit. (nota 19), p. 28 e ss., cada qual com ulteriores indicações.

26 De acordo com seu criador, Carpzov (1595-1666), o dolo do autor se estende também àquilo que se segue diretamente e per se ao fato ("quod inmediater et per se sequitur"). Quem, por exemplo, dolosamente perfura alguém com uma espada tem dolo indireto de matar, porque a sua vontade não se relaciona à perfuração, mas a tudo o que se segue como consequência imediata dela, mesmo que o autor não o deseje; sobre o tema, com informações sobre a fonte e tradução, cf. PUPPE, ob. cit. (nota 19), p. 24 e ss.

27 JAKOBS, ob. cit. (nota 25), p. 593 e ss.; demonstração de outras abordagens, principalmente por parte dos discípulos de Jakobs, em GAEDE, ob. cit. (nota 25), p. 248 e ss.; mais aprofundado e crítico sobre a abordagem de Jakobs a partir de uma perspectiva jurídico-filosófica, BUNG, ob. cit. (nota 24), p. 25 e ss. 
dolo ${ }^{28}$. De todo modo, em sua variante mais radical, que é a encontrada em Jakobs, a normativização do dolo tem sido consistentemente recusada. Ele defende essencialmente o seguinte: o dolo deve ser reconhecido independentemente de o autor refletir ou não sobre a realização do tipo, desde que o conhecimento das circunstâncias fáticas Ihe seja indiferente, no sentido de que seria irrelevante para sua decisão, isto é, de que o autor também teria agido ainda que tivesse conhecimento dos fatos. Isso porque, em tais casos, a exclusão da punição dolosa se mostra um privilégio injustificável, que tampouco seria exigido de lex lata: considerar a indiferença como dolo corresponde à regulação do erro de proibição do §17 2 StGB; o §16 I 1 StGB precisaria ser interpretado racionalmente, de modo que o desconhecimento irrelevante para a decisão não seja abrangido e também o $\$ 18$ StGB deveria ser limitado à realização do resultado por erro culposo ${ }^{29}$. A crítica aqui aponta, com razão, que essa abordagem significa, à luz do art. 103 II GG (Grundgesetz, Lei Fundamental alemã), uma redução teleológica contra o réu muito pouco justificável, a qual dificilmente pode explicar a existência de delitos qualificados pelo resultado (\$18 StGB) ${ }^{30}$, e que, além disso, em última instância, tende à punição de um dolo meramente hipotético ${ }^{31}$. No Direito Penal Internacional, afirma-se, ademais, que a abrangência da cegueira intencional no dolo configuraria uma violação do princípio da culpabilidade ${ }^{32}$.

De acordo, portanto, com a teoria volitiva do dolo psicologicamente orientada, sustentada pela opinião dominante, o dolo do dirigente de empresa é afastado quando ele não tenha reconhecido o risco de cometimento de crimes por subordinados ou, ao menos, quando haja confiado na não realização de um risco conhecido. Não importa se essa confiança pode ser reconduzida a mecanismos intrapsíquicos (repressão, controle de estresse) ou a medidas organizacionais para evitar a obtenção de informações comprometedoras. A reprovabilidade da falta de conhecimento ou da especial leviandade da confiança é irrelevante e só pode desempenhar um papel na realização de delitos culposos. A representação de um dirigente empresarial de que seus funcionários não cometem quaisquer infrações pode, portanto, justificar a exclusão do dolo, mesmo se for baseada na recusa em lidar com as ocorrências relevantes no sentido da doutrina da cegueira delibera-

SCHÜNEMANN, ob. cit. (nota 18), p. 365, fala de "limitada" e "totalmente pós-moderna objetivação".

29 JAKOBS, ob. cit. (nota 25), p. 593 e ss., 597 e s.

30 Parcialmente reconhecido por JAKOBS, ob. cit. (nota 25), p. 598.

31 Críticas concisas em VOGEL, GA 2006, p. 388 e s.; especificamente GAEDE, ob. cit. (nota 25), p. 262 e ss.; também KINDHÄUSER, FS-Eser, p. 345 e ss.; aprofundado, SCHÜNEMANN, ob. cit. (nota 18), p. 372 e s. 
da. Uma valoração diferente só pode ser feita se a decisão de "defesa" contra certas informações for, em última análise, já uma consequência do reconhecimento do crime como possível e do respectivo consentimento. Uma evitação intencional do dolo não pode existir conceitualmente, porque, quando alguém tem uma razão para propositalmente evitar o próprio dolo, ele já existe.

O conceito predominante de dolo psicologicamente fundado pode, porém, ter por consequência um aumento do risco jurídico-penal para os dirigentes empresariais que lidam escrupulosamente com uma iminente lesão a interesses de terceiros, enquanto a indiferença em relação aos fatos acaba desonerando-os de modo eficaz. Antes de, a partir disso, concluir por um argumento a favor de uma normativização mais forte do dolo ${ }^{33}$, deve-se ter em mente que a área problemática é significativamente reduzida na medida em que, ao lado dos critérios conceituais, leva-se em conta a determinação processual do dolo ${ }^{34}$.

\section{A determinação processual do dolo}

\subsection{Ponto de partida}

Ainda que o conceito de dolo, no sentido jurídico-material, seja essencialmente baseado em fatores psíquicos, uma normativização é, de todo modo, inevitável no contexto da prova processual, porque os fatos internos não são imediatamente acessíveis à observação ${ }^{35}$. Se o réu se cala ou nega ter tido consciência da realização do tipo, deve o juiz decidir, baseado em circunstâncias e indícios externos e no âmbito do livre convencimento judicial (cf. §261 StPO [Strafprozeßordnung, Código de Processo Penal alemão]), sobre a presença dos pressupostos psíquicos do dolo ${ }^{36}$. Embora os critérios jurídico-materiais do dolo na jurisprudência do BGH estejam cada vez mais consolidados e raramente sejam objeto de discussão profunda, a revisão dos julgados sobre a prova do dolo oferece um quadro díspar e rico ${ }^{37}$, no qual o ponto de cristalização é constante-

Assim JAKOBS, ob. cit. (nota 25), p. 588; parcialmente também PUPPE, ob. cit. (nota 19), p. 13 e s.

34 A respeito, GAEDE, ob. cit. (nota 25), p. 255 e ss.; para a diferenciação entre critérios jurídico-materiais e determinação processual do dolo, cf. FRISCH, ob. cit. (nota 19), p. 535 e s.; HILLENKAMP, GS-Armin Kaufmann, p. 360 e s.

35 LKStGB-Vogel, Vor $\$ 15$ nm. 71; SCHROTH, ob. cit. (nota 18), p. 780; PUPPE, ob. cit. (nota 19), p. 11.

36 V. somente MüKoStPO-Miebach, §261 nm. 126 com outras referências; RISSING-VAN SAAN, ob. cit. (nota 13), p. 502 e ss.; mais recentemente HRUSCHKA, FS-Kleinknecht, p. 194 e ss., que fala de uma atribuição do dolo fundada em circunstâncias externas; compare-se também SCHÜNEMANN, ob. cit. (nota 18), p. 367 e s.

Mais recentemente, sobre essa discrepância, VOLK, Münchener Anwaltshandbuch, §2 nm. 45 e ss. 
mente a questão do dolo eventual de matar nas condutas violentas especialmente perigosas ${ }^{38}$. $\mathrm{O}$ BGH exige aqui uma "visão geral de todas as circunstâncias fáticas objetivas e subjetivas do caso concreto, na qual devem ser abrangidos, acima de tudo, a periculosidade objetiva da ação, o modo concreto de ataque do agente, seu estado mental no momento do cometimento do fato e sua situação motivacional" ${ }^{39}$. Entretanto, há uma extensa casuística sobre a importância de diferentes espécies de indícios ${ }^{40}$. Particularmente obscuro neste contexto é o constantemente utilizado topos, crítico ao dolo, da inibição diante de homicídios, sobre cujo significado nem mesmo entre as distintas turmas de julgamento (Senaten) do $\mathrm{BGH}$ há uma clareza definitiva ${ }^{41}$. O critério da suposta inibição diante do homicídio provavelmente só pode ser aplicado, de modo convincente, como um entre vários indicadores que, no contexto da consideração geral requerida, em última análise, não tem nenhuma importância proeminente ${ }^{42}$.

É claro que essa jurisprudência, gerada em conexão com os $§ \S 211$ e 212 StGB, não pode ser aplicada diretamente às constelações de casos aqui tratadas ${ }^{43}$. No contexto do tipo subjetivo, os entendimentos dogmáticos apresentados no âmbito do Direito Penal Econômico discutem, sobretudo, questões de erro sobre elementos normativos do tipo e tipos penais em branco, ao passo que, do ponto de vista da dogmática geral do dolo, raramente são discutidas essas especificidades $^{44}$. Com efeito, a jurisprudência relacionada à norma da infidelidade patrimonial (\$266 StGB) sempre estabeleceu exigências particularmente rigorosas para a prova do dolo, especialmente quando se trata apenas de dolo eventual diante de um assim chamado perigo patrimonial equivalente ao dano em negócios de

38 Mais recentemente, FRANKE, StraFo 2016, p. 269 e ss.

39 Em tempos mais recentes, BGH NStZ-RR 2013, 75 (76 e s.).

40 Uma avaliação tanto instrutiva quanto amplamente crítica desta jurisprudência com numerosas demonstrações pode ser encontrada em MüKoStGB-Schneider, $\$ 212$ nm. 6 e s.; um tanto mais resumido, SCHROTH, ob. cit. (nota 18), p. 791 e ss.

41 Comparar, nessa medida, a decisão da 4 a Turma Penal eventualmente identificada como "teoria do fim da inibição" em BGHSt 57, 183 = NJW 2012, 1524 (1526 e s.); com outras tendências, por outro lado, BGH NStZ-RR 2012, 369 e s. (4 ${ }^{\text {a }}$ Turma Penal); comparar também BGH NStZ 2014, 35 ( $2^{\text {a }}$ Turma Penal) com notas organizativas de Schiemann; diferenciação sobre a teoria do fim da inibição, cf. SCHROTH, ob. cit. (nota 18), p. 788 e ss.

42 Mais recentemente RISSING-VAN SAAN, ob. cit. (nota 13), p. 504 e ss.; similar também BGH NJW 2012, 1524 (1526 ao final): a teoria do fim da inibição se exaure em uma referência ao §261 StPO.

43 Claramente (sobre infidelidade de crédito) BGHSt 46, 30 = NJW 2000, 2364 (2365 e ss.).

44 Por exemplo, WITTIG, Wirtschaftsstrafrecht, $\$ 6 \mathrm{~nm} .157$ e ss.; TIEDEMANN, Wirtschaftsstrafrecht AT, nm. 336 e ss; sobre erros em modificações delitivas específicas no Direito Penal Econômico, também VOLK, ob. cit. (nota 37), §2 nm. 42. 
risco ${ }^{45}$. Mas a casuística aqui não apenas é muito menos diferenciada do que nos homicídios, mas está intimamente relacionada às peculiaridades da infidelidade patrimonial nos negócios de risco e no perigo patrimonial equivalente ao dano ${ }^{46}$. No que diz respeito a esta última figura jurídica, os princípios também foram transportados para o dolo de prejudicar no estelionato ${ }^{47}$. Mais recentemente, o debate afastou-se dos pressupostos subjetivos em direção a critérios objetivos de restrição em casos de perigo patrimonial equivalente ao dano ${ }^{48}$.

Quando, a seguir, são discutidas questões da determinação processual do dolo dos dirigentes empresariais em relação aos crimes relacionados à empresa cometidos por subordinados, deve-se partir de uma função orientadora da jurisprudência sobre o dolo eventual de matar, na medida em que os princípios ali desenvolvidos se revelarem transponíveis. Naturalmente, a jurisprudência sobre infidelidade patrimonial também será levada em conta, quando materialmente apropriada. Em qualquer caso, não se deve perder de vista que a determinação processual do dolo é um domínio original do juiz criminal, sobre o qual, independentemente dos fatos concretos e de sua prova no processo, são possíveis apenas declarações abstratas muito limitadas ${ }^{49}$.

\subsection{0 elemento cognitivo do dolo}

Para a avaliação do elemento cognitivo do dolo, é crucial verificar quão alto era o risco da prática de crimes relacionados à empresa de um ponto de vista objetivo, isto é, sob a perspectiva de um observador razoável ${ }^{50}$. Isso corresponde ao critério do perigo à vida decorrente de atos violentos na determinação do dolo de matar, que possui normalmente um valor probatório considerável (embora não absoluto). Quando, devido a circunstâncias específicas, deva-se contar, em considerável medida, com o risco de cometimento de delitos pelos subordinados, um dirigente empresarial não pode, normalmente, alegar que não estaria consciente

Ver por exemplo, BGH NJW 1990, 3219 (3220); BGH NJW 2000, 2364 (2365 e s.); BGHSt 47, 148 = NJW 2002, 1211 (1215 e s.).

Análise aprofundada com indicações introdutórias em HILLENKAMP, FS-Maiwald, p. 326.

BGHSt 48, 331 = NJW 2004, 375 (379 e s.); BGH NStZ-RR 2008, 239 e s.

48 Sobre esse desenvolvimento, por exemplo, BECKER, HRRS 2009, p. 334 e ss.; mais recente e introdutório, ENSENBACH, Prognoseschaden bei der Untreue, p. 187 e ss., com outras referências. em tempos recentes, BGH NStZ-RR 2013, 89 (90); sobre a "saturação" do conceito de dolo pelo juiz do fato fala SCHROTH, ob. cit. (nota 18), p. 788. 
desse risco. Meras dúvidas abstratas, para as quais não existe nenhum ponto de referência real, não impedem a afirmação do dolo ${ }^{51}$.

Se, por exemplo, os representantes de vendas obtêm grandes encomendas em um ambiente regional e/ou material em que, como é sabido, isso é praticamente impossível sem o pagamento de propinas, entra em questão a admissão judicial do elemento cognitivo do dolo se o dirigente empresarial afirma que ele não esperava a prática de crimes de corrupção. Entretanto, além da mera atividade comercial em uma região correspondente, provavelmente será necessário exigir indicadores adicionais em relação à conclusão de um negócio específico, porque não é fácil verificar permanentemente todas as transações em determinados países ${ }^{52}$. Se forem estabelecidas metas manifestamente inatingíveis para os subordinados, é natural que o juiz criminal possa concluir, apesar das alegações em contrário, pela existência (no mínimo) do conhecimento da administração sobre a possibilidade de infrações. Indícios de estresse, sobrecarga, repressão ou outras circunstâncias psicológicas normais não formam, nessa medida, um empecilho para a aceitação do elemento cognitivo do dolo ${ }^{53}$. No entanto, uma defesa crível de que o réu tratou de modo extremamente superficial certas questões pode fundamentar um indício contrário à existência do elemento cognitivo do dolo ${ }^{54}$.

$\mathrm{O}$ efeito de perigo à vida manifestado em tiros de pistola, facadas e outros atos de violência é, porém, parte de um conhecimento empírico geral que pode fundamentalmente ser tomado como pressuposto para todo réu mentalmente são ${ }^{55}$. O mesmo não pode ser dito, sem mais, sobre o risco de cometimento de delitos por subordinados em empresas. A esse respeito, o BGH salientou, corretamente, no contexto de casos de Direito Penal patrimonial, que, no caso de eventos complexos e ambíguos, uma avaliação do dolo baseada apenas na situação de risco objetiva é preocupante ${ }^{56}$. A alegação de um dirigente de empresa de que não reconheceu o risco de cometimento de crimes pode, portanto, ser considerada pelo juiz criminal como um indício contrário à prova do dolo, se faltava ao réu uma visão suficiente sobre as unidades de negócio envolvidas que,

52 Nesse sentido, com razão, KUHLEN, NZWiSt 2015, p. 128 contra LG München (Tribunal Regional de Munique), I ZIP 2014, 570 (575) - "Siemens/Neubürger".

53 Compara-se BGH NStZ-RR 2003, 8 e s. Com mais detalhes e outras indicações, MüKoStGB-Schneider, §212, nm. 9.

54 Nesse sentido, FRISCH, ob. cit. (nota 19), p. 558, com outras referências.

55 Ver, por exemplo, BGH NStZ-RR 1996, 323, sobre tiros em pessoas com arma de fogo; NStZ 2004, 201 (202), sobre agitar violentamente uma criança.

56 BGH NJW 2000, 2364 (2365 e s.), com outras referências. 
consequentemente, tornasse plausível um erro de avaliação do risco. Isso deve ser especialmente considerado no caso de um órgão colegiado com vários membros se os delitos são cometidos fora da área de competência de um deles ${ }^{57}$, pelo que o BGH, em sua fundamental "decisão sobre o spray de couro", postulou, para certas constelações de casos, uma obrigação de monitoramento e controle interdepartamental dentro desses órgãos ${ }^{58}$. Se um dirigente nunca trabalhou efetivamente em vendas, ele pode não estar ciente de práticas corruptas em certas regiões do mundo ou segmentos de mercado. Quem formula metas de vendas em relação a determinados departamentos só reconhece um risco relacionado de infrações se os procedimentos e as condições do respectivo departamento lhe forem razoavelmente familiares. Se, de acordo com o caso concreto, houver indicadores confiáveis e fáticos de que um risco objetivamente existente pode não ter sido reconhecido devido à ausência de conhecimento setorial específico ou de ausência de competência do dirigente acusado, isso deve ser discutido pelo juiz no âmbito da valoração probatória e pode sugerir a negativa do elemento cognitivo do dolo. Questões equivalentes se colocam, naturalmente, já para o Ministério Público em um estágio preliminar, quando examina se os fatos averiguados são suficientes para justificar uma acusação contra os dirigentes empresariais.

\subsection{0 componente volitivo}

Se o componente cognitivo do dolo for apurado corretamente, será ainda necessária outra valoração probatória: se o réu, apesar da reconhecida possibilidade de realização do tipo, poderia ter confiado seriamente em sua não ocorrência e, desse modo, agido com culpa consciente ${ }^{59}$. Também aqui o risco objetivo constitui o ponto de partida decisivo, razão pela qual o BGH, no contexto de homicídios, valora a elevada e explícita periculosidade à vida do comportamento do agressor como o indicador decisivo de ambos os elementos do dolo ${ }^{60}$. Também em casos de dolo relacionados ao perigo ao patrimônio equiparado a dano, a extensão e a obviedade da situação de risco são indícios centrais no que se refere

57 Compare-se, sobre os limites da competência como limites à imputação de conhecimento à pessoa jurídica, WELLER, ob. cit. (nota 5), p. 406 e s.

58 Sobre isso, RÖNNAU, GmbHG, §82 nm. 33, com outras referências.

59 Sobre a exigência do exame separado baseado em fatos dos dois componentes do dolo, v. recentemente, por exemplo, BGH NStZ-RR 2016, 204 ao final.

60 Compare-se, recentemente, BGH NStZ-RR 2016, 204; NJW 2016, 1970 (1971); outras indicações em MüKoStGB-Schneider, $\$ 212 \mathrm{~nm}$. 65, nota de rodapé 231; v. também RISSING-VAN SAAN, ob. cit. (nota 13), p. 503. 
aos dois elementos do dolo ${ }^{61}$. Isso significa, no presente contexto, que a conclusão judicial sobre o dolo eventual do dirigente da empresa é igualmente possível, também sob o ponto de vista da vontade, em regra, se na situação concreta o risco de cometimento de crimes relacionados à empresa pelos empregados era claramente extremamente alto. Em geral, a alegação de que o réu não tinha conhecimento desse risco ou confiava na ausência de sua realização não impede, por si, a determinação do dolo eventual. Por outro lado, indícios contrários ao dolo devem ser apreciados pelo juiz criminal, sobretudo ao examinar o componente volitivo, sempre que existam indicações plausíveis, faticamente embasadas e não meramente vagas, para a confiança do acusado na ausência de realização do tipo, pelo que, mesmo que o risco de realização do tipo seja, do ponto de vista objetivo, particularmente alto, a necessária apreciação global não pode ser completamente omitida ${ }^{62}$. Como os contextos nos crimes econômicos são geralmente mais complexos e ambíguos do que em atos de violência perigosos à vida (vide Seção 2.2, supra), é especialmente importante advertir contra uma conclusão irrefletida sobre o consentimento subjetivo do acusado somente com base na situação de risco objetiva ${ }^{63}$.

A esse respeito, o $\mathrm{BGH}$ exige, além da consideração de fatores objetivos de risco, também fundamentalmente a compreensão dos motivos da conduta do acusado $^{64}$, sua personalidade ${ }^{65}$ e seu comportamento posterior ao fato ${ }^{66}$. Em princípio deve ser levada em conta, portanto, a atitude do dirigente acusado até aquele momento em relação às infrações ou aos seus esforços para evitá-las em situações anteriores ${ }^{67}$. Além disso, tentativas subsequentes de esclarecer o evento podem, sob certas circunstâncias, constituir um indício contra a admissão do dolo eventual. No entanto, esses critérios derivam principalmente de decisões que têm por objeto homicídios particularmente espontâneos e passionais (sobretudo diante de crianças pequenas) ${ }^{68}$. Uma transposição apropriada para os casos

BGH NJW 2002, 1211 (1216); NJW 2004, 375 (379 in fine).

62 V., recentemente, BGH NJW 2016, 1970 (1971) com outras referências; compare-se também BGH NStZ-RR 2008, 239 (240); RISSING-VAN SAAN, ob. cit. (nota 13), p. 503; MüKoStGB-Schneider, §212 nm. 22: nenhum "manejo sistemático"; mais aprofundado e com exemplos, SCHNEIDER, FS-Dahs, p. 190 e ss.

64 BGH NStZ 2011, 338 (339), com outras referências.

65 BGH NStZ-RR 2012, 369 (370), com outras referências.

66 BGH NStZ 2007, 331 (332), com outras referências.

67 Compare-se, sobre isso, BGH NStZ 1988, 175; v. também (sobre o dolo na lesão corporal) BGH NStZ 2004, 201 (202) com anotações críticas de Schneider; ademais, FRISCH, ob. cit. (nota 19), p. 557.

68 Avaliação detalhada e crítica dessa jurisprudência, com numerosas indicações, em MüKoStGB-Schneider, \$212 nm. 35 e ss. 
da criminalidade econômica é, na melhor das hipóteses, muito restrita, uma vez que - especialmente o critério frequentemente criticado do ponto de vista do dolo nos casos de homicídio do comportamento passional/irrefletido e espontâneo ${ }^{69}-$, frequentemente, não desempenhará um papel comparativamente grande no comportamento dos dirigentes empresariais. De todo modo, é duvidoso em que medida as circunstâncias mencionadas devem servir de fundamento para uma confiança séria e faticamente embasada do acusado na ausência do cometimento do delito reconhecida como possível ${ }^{70}$. Os motivos do réu podem fornecer indícios, em primeiro lugar, quando a realização do tipo é, de seu ponto de vista, obviamente contrária ao seu interesse ${ }^{71}$. Além disso, a falta de proveito próprio derivada da prática pode ser um fator contrário ao dolo na valoração probatória ${ }^{72}$. No entanto, um interesse pessoal indireto qualquer deve ser levado em conta, como sucede, por exemplo, se os pagamentos de bônus forem devidos quando as metas corporativas forem atingidas.

Como não basta uma confiança vaga e não baseada em fatos na não realização da conduta típica que, todavia, foi reconhecida como possível, é de particular importância a controlabilidade do risco ${ }^{73}$. No caso de riscos incontroláveis, na visão do $\mathrm{BGH}$, a conclusão sobre a aprovação da realização do risco é frequentemente suposta ${ }^{74}$. Sobretudo, os sistemas de conformidade (compliance) podem ser adequados para evitar a prática de crimes na empresa ${ }^{75}$. Ausente sua instituição, apesar do risco objetivamente elevado de cometimento de crimes, isso pode sugerir a existência de dolo eventual ${ }^{76}$. Porque aqueles que não tomam nenhuma medida, apesar de evidências robustas de um ambiente de negócios criminógeno, expressam com isso que, ao fim e ao cabo, abandonam a realização

69 Compare-se, por exemplo, BGH NStZ 2009, 629 (630), com outras referências.

70 Criticado com razão em MüKoStGB-Schneider, \$212 nm. 38.

71 Compare-se, sobre isso, BGH NStZ-RR 2006, 317 (318); BGH decisão de 29.9.1999 - 2 StR 349/99 em ALTVATER, NStZ 2000, 18 (19); FRISCH, ob. cit. (nota 19), p. 560.

72 BGH NJW 1990, 3219 (3220).

73 Aplicável a este respeito BGH NJW 1990, 3219 (3220); compare-se também (sobre o dolo concernente ao perigo de dano patrimonial), VOLK, ob. cit. (nota 37 ), $\$ 2 \mathrm{~nm} .51$ e ss.

74 BGH NJW 2002, 1211 (1216); em geral, sobre o significado indiciário das medidas de prevenção, FRISCH, ob. cit. (nota 19), p. 538, com outras referências; ademais HILLENKAMP, ob. cit. (nota 34), p. 351 e ss.

75 Recentemente, sobre a justificativa e os limites de um dever de conformidade, KUHLEN, NZWiSt 2015, p. 126 e ss. e passim, com outras referências.

76 Ver também KUHLEN, NZWiSt 2015, p. 126, nota de rodapé 82; em geral sobre a omissão de possíveis medidas de prevenção como indício, HILLENKAMP, ob. cit. (nota 34), p. 365 e s. 
do risco ao acaso ${ }^{77}$. Por outro lado, um sistema de conformidade instalado e efetivo, com a instituição de deveres de comunicação dos empregados responsáveis aos dirigentes da empresa ${ }^{78}$, pode ser um indício contra a admissão do dolo eventual porque indica uma base fática concreta e confiável que permite supor que, em princípio, o risco inerente ao cometimento de delitos seria controlável ${ }^{79}$. No entanto, quando a conformidade só ocorre "no papel" ou se esgota em uma mera fachada, ela não é levada em consideração como indício excludente do dolo, porque, nesse ambiente, o dirigente não pode confiar que é capaz de controlar o perigo por meio de um departamento de conformidade ineficaz e instituído apenas pro forma. Por outro lado, a explicação crível de ter superestimado a capacidade do sistema de conformidade pode, em algumas circunstâncias, justificar a conclusão pela falta de dolo ${ }^{80}$. Para isso, deve sempre ser verificado se os esforços de controle e evitação das condutas realmente produzem uma confiança do agente na não realização do tipo ou se simplesmente reduzem um risco elevado ${ }^{81}$.

Finalmente, revela-se ambivalente, no contexto da determinação do dolo, a avaliação de medidas de impedimento informacional diante de âmbitos empresariais potencialmente criminógenos. Dependendo da estrutura organizacional e da distribuição de competências, a alegação do réu de que ele não tinha conhecimento de determinadas circunstâncias de risco relevantes pode ser inteiramente crível e plausível, fundamentando, assim, a conclusão pela ausência já do componente cognitivo do dolo (ver Seção 2.2, supra). Pelo contrário, uma falha em se ocupar de eventos potencialmente relevantes do ponto de vista jurídico-penal, ignorando advertências e indicações concretas, pode justificar a conclusão pela indiferença e pela ausência de domínio do risco e, assim, contribuir para a afirmação do dolo eventual. Aqui se evidencia como o processo penal mitiga o problema da preferência pela indiferença em relação aos fatos, um problema aparentemente fundado na concepção psicológica em sentido jurídico-material. Qualquer pessoa que, apesar de indícios óbvios de cometimento de delitos, permaneça inativa e possivelmente até se recuse a seguir indicações recebidas, di-

77 Além disso (em conexão com a punibilidade de acordo com os $\S \S 263$, 263a StGB no chamado processo "WAP-Billing"), WEGNER, NStZ 2016, p. 458.

78 Sobre a possibilidade e os limites da delegação dos deveres de conformidade, ZIMMERMANN, Strafbarkeitsrisiken durch Compliance, p. 171 e ss.

79 Sobre a interação entre compliance e o $\$ 130$ OWiG (possível exclusão típica ou consideração no contexto do cálculo da multa), comparar a síntese de RÖNNAU, ZGR 45, p. 293 e s.

80 Em geral, sobre o erro de avaliação do perigo como indício relevante para o dolo, FRISCH, ob. cit. (nota 19), p. 556 e s., com outras referências.

81 Compare-se, sob esse aspecto, HILLENKAMP, ob. cit. (nota 34), p. 359. 
ficilmente poderá alegar com sucesso no processo penal, diante de indícios objetivos robustos, que não reconheceu os perigos envolvidos ou que, pelo menos, não assentiu com sua realização. Quem, por outro lado, lida com tais eventos e toma contramedidas sérias, gera indícios de uma confiança baseada em fatos na controlabilidade do risco reconhecido, o que pode produzir um efeito contrário ao dolo na avaliação judicial.

\section{Responsabilidade de acordo com $0 \$ 130$ OWiG}

O §130 I OWiG 82 compreende, como destinatário da norma, o "titular de um estabelecimento ou empresa" e sanciona a omissão de medidas de supervisão "necessárias para evitar infrações de deveres no estabelecimento ou na empresa, os quais recaem sobre o titular e cuja infração seja punível com prisão ou multa". O dispositivo é uma "norma de conformidade nata" ("geborene Compliance-Norm"), que, em conjunto com o $\$ 9 \mathrm{OWiG}$, estabelece a responsabilidade dos órgãos de gestão (em lugar do titular do estabelecimento ou da empresa, legalmente apontado) pelas medidas de supervisão exigidas e, junto com o $\S 30$ da mesma lei, pode ter por consequência a imposição de multas elevadas contra a empresa. Embora os detalhes da regulamentação não possam ser aqui descritos com maior profundidade, uma rápida indicação é relevante no nosso contexto, porque o dispositivo é aplicável já nos casos de (mera) omissão culposa de adoção de medida de supervisão, desde que fosse necessária e razoável e sempre que a infração "tivesse sido evitada ou consideravelmente dificultada pela supervisão adequada".

Para os órgãos de persecução penal, trata-se, portanto, de uma ferramenta bastante eficaz, tendo em vista as possibilidades de sanções financeiras disponíveis nos casos em que a prova do dolo eventual não pareça suficiente e não exista - como é frequente no Direito Penal Econômico - a possibilidade de punição por culpa. E é eficaz, ademais, porque a infração exigida na lei, ou seja, o crime ou a contraordenação cometido por um empregado, é concebida como uma condição objetiva de punibilidade, de modo que, relativamente a ela, nem mesmo é necessária uma conduta culpável daqueles obrigados a adotar as medidas de supervisão. 


\section{Conclusão}

Uma contribuição criminalmente relevante dos dirigentes empresariais em crimes dolosos relacionados à empresa cometidos por subordinados pressupõe pelo menos o dolo eventual quanto ao cometimento de tais crimes. Isso exige, do ponto de vista jurídico-material, que o agente leve seriamente em conta a possibilidade da prática de tais crimes e concorde com seu cometimento ou com eles consinta (em sentido jurídico). Por outro lado, se o dirigente confia sinceramente na não ocorrência do risco por ele reconhecido, não haverá dolo, independentemente de essa confiança, efetivamente existente na mente do perpetrador, ser produto de repressão, indiferença ou simples desconsideração de sinais óbvios. Do ponto de vista processual, a conclusão judicial sobre a admissão do dolo eventual se mostrará possível e, portanto, fático-juridicamente autorizada se, objetivamente, houver um risco significativo de cometimento de crimes e não houver indícios de que eles foram mal compreendidos ou desaprovados. Nesse sentido, devem ser levados em consideração, como indícios contrários ao dolo, sobretudo medidas de conformidade ou outros instrumentos eficazes para o controle de riscos, dos quais se pode derivar uma confiança faticamente fundada do dirigente empresarial na não ocorrência do evento criminoso. Quando não houver prova do dolo, deve-se observar, na prática, especialmente o disposto no $\$ 130$ OWiG, que autoriza a aplicação de sanções financeiras substanciais contra a empresa nos casos de omissão culposa de medidas de supervisão.

\section{Referências}

ACHENBACH, Hans. Zurechnung unternehmensbezogenen Handelns. In: ACHENBACH, Hans; RANSIEK, Andreas; RÖNNAU, Thomas (Hrsg.). Handbuch Wirtschaftsstrafecht. 4. Auflage. Heidelberg: C.F. Müller, 2015.

ALTVATER, Gerhard. Rechtsprechung des BGH zu den Tötungsdelikten. Neue Zeitschrift für Strafrecht, [s.I.], p. 18-24, 2000.

AMBOS, Kai. Internationales Strafrecht: Strafanwendungsrecht Völkerstrafrecht - Europäisches Strafrecht - Rechtshilfe. 4. Auflage. München: C.H. Beck, 2014.

BECKER, Christian. Paradigmenwechsel in der Schadensdogmatik oder "Viel Lärm um nichts"? Zur aktuellen Kontroverse um die sog. "schadensgleiche Vermögensgefährdung". Onlinezeitschrift für Höchstrichterliche Rechtsprechung zum Strafrecht, [s.I.], v. 10, n. 8/9, p. 334-340, 2009. 
BUCK-HEEB, Petra. §2. In: HAUSCHKA, Christoph E.; MOOSMAYER, Klaus; LÖSLER, Thomas (Hrsg.). Corporate Compliance: Handbuch der Haftungsvermeidung im Unternehmen. 3. Auflage. München: C.H. Beck, 2016.

BÜLTE, Jens. Vorgesetztenverantwortlichkeit im Strafrecht. Baden-Baden:

Nomos Verlag, 2015.

BUNG, Jochen. Wissen und Wollen im Strafrecht: zur Theorie und Dogmatik des subjektiven Tatbestands. Frankfurt am Main: Klostermann, 2009.

ENSENBACH, Kai. Prognoseschaden bei der Untreue: vom "Gefährdungsschaden" zur wirtschaftlichen Prognose anhand der Sicherheitslösung. Tübingen: Mohr Siebeck, 2016.

FISCHER, Thomas. Strafgesetzbuch. 63. Auflage. München: C.H. Beck, 2016.

FRANKE, Ulrich. Die Beweiswürdigung in der Revision - insbesondere die Abgrenzung von bedingtem Vorsatz zur Fahrlässigkeit. Strafverteidiger Forum, [s.I.], p. 269-274, 2016.

FRISCH, Wolfgang. Gegenwartsprobleme des Vorsatzbegriffs und der Vorsatzfeststellung am Beispiel der AIDS-Diskussion. In: GEPPERT, Klaus (Hrsg.). Gedächtnisschrift für Karlheinz Meyer. Berlin: De Gruyter, 1990. p. 533-566.

FRISCH, Wolfgang. Vorsatz und Risiko. Köln: Heymann, 1983.

GAEDE, Karsten. Auf dem Weg zum potentiellen Vorsatz? Problematik und Berechtigung der zunehmenden Tendenzen zur normativen Relativierung des Vorsatzerfordernisses. Zeitschrift für die Gesamte Strafrechtswissenschaft, Berlin, v. 121, n. 2, p. 239-280, 2009. DOI: 10.1515/ZSTW.2009.239.

GAEDE, Karsten. §15. In: MATT, Holger; RENZIKOWSKI, Joachim (Hrsg.). Strafgesetzbuch: Kommentar. München: Vahlen, 2013.

HASSEMER, Winfried. Kennzeichen des Vorsatzes. In: DORNSEIFER, Gerhard (Hrsg.). Gedächtnisschrift für Armin Kaufmann. Köln: Heymann, 1984. p. 289-309.

HERZBERG, Rolf Dietrich. Die Abgrenzung von Vorsatz und bewußter Fahrlässigkeit - ein Problem des objektiven Tatbestandes. Juristische Schulung, [s.I.], v. 26, p. 249-262, 1986.

HEß, Josef. Steuerstrafrechtliche Aspekte bei der Manipulation von PkwSchadstoffmessungen. Zeitschrift für Wirtschafts- und Steuerstrafrecht, [s.I.], n. 6, p. 212-215, 2016.

HILLENKAMP, Thomas. 32 Probleme aus dem Strafrecht: Allgemeiner Teil. 14. Auflage. München: Verlag Franz Vahlen, 2012. 
HILLENKAMP, Thomas. Dolus eventualis und Vermeidewille. In: DORNSEIFER, Gerhard (Hrsg.). Gedächtnisschrift für Armin Kaufmann. Köln: Heymann, 1984. p. 351-369.

HILLENKAMP, Thomas. Zur Kongruenz von objektivem und subjektivem Tatbestand der Untreue. In: BLOY, René (Hrsg.). Gerechte Strafe und legitimes Strafrecht: Festschrift für Manfred Maiwald zum 75. Geburtstag. Berlin: Duncker \& Humblot, 2010. p. 323 ss.

HRUSCHKA, Joachim. Über Schwierigkeiten mit dem Beweis des Vorsatzes. In: GÖSSEL, Karl Heinz (Hrsg.). Strafverfahren im Rechtsstaat: Festschrift für Theodor Kleinknecht zum 75. Geburtstag am 18. August 1985. München: Beck, 1985. p. 191-202.

ISFEN, Osman. Mehr Schein als Sein - die VW-Abgasaffäre aus strafrechtlicher Sicht. Juristische Arbeitsblätter, [s.I.], p. 1-6, 2016.

JAKOBS, Günther. Gleichgültigkeit als dolus indirectus. Zeitschrift für die Gesamte Strafrechtswissenschaft, Berlin, v. 114, n. 3, p. 584-599, 2002. DOI: 10.1515/ zstw.2002.114.3.584.

JOECKS, Wolfgang. §16. In: HEINTSCHEL-HEINEGG, Bernd von (Herausgeber). Münchener Kommentar zum Strafgesetzbuch. 2. Auflage. München: C.H. Beck, v. 1, 2011.

KINDHÄUSER, Urs. Gleichgültigkeit als Vorsatz? In: ARNOLD, Jörg (Hrsg.). Menschengerechtes Strafrecht: Festschrift für Albin Eser zum 70. Geburtstag. München: Beck, 2005. p. 345-358.

KUHLEN, Lothar. Zum Verhältnis von strafrechtlicher und zivilrechtlicher Haftung für Compliance-Mängel, Teil 1. Neue Zeitschrift für Wirtschafts-, Steuer- und Unternehmensstrafrecht, [s.I.], v. 4, n. 4, p. 121-129, 2015.

LUBAN, David. Contrived ignorance. Georgetown Law Journal, [s.I.], v. 87, p. 957-980, 1999.

MARCUS, Jonathan L. Model Penal Code Section 2.02(7) and willful blindness. Yale Law Journal, [s.I.], v. 102, p. 2231-2257, 1993.

MIEBACH, Klaus. \$261. In: SCHNEIDER, Hartmut (Hrsg.). Münchener Kommentar zur Strafprozessordnung. München: C.H. Beck, v. 2, 2016.

PUPPE, Ingeborg. \$15. In: KINDHÄUSER, Urs; NEUMANN, Ulfrid; PAEFFGEN, Hans-Ulrich. Strafgesetzbuch. 4. Auflage. Baden-Baden: Nomos Verlag, 2013.

PUPPE, Ingeborg. Der Vorstellungsinhalt des dolus eventualis. Zeitschrift für die Gesamte Strafrechtswissenschaft, Berlin, v. 103, n. 1, p. 1-42, 1991. DOI: 10.1515/zstw.1991.103.1.1. 
RISSING-VAN SAAN, Ruth. Der bedingte Tötungsvorsatz und die Hemmschwellentheorie des Bundesgerichtshofs. In: GEISLER, Claudius (Hrsg.). Festschrift für Klaus Geppert zum 70. Geburtstag am 10. März 2011. Berlin: De Gruyter, 2011. p. 497-518.

ROGALL, Klaus. \$130. In: SENGE, Lothar (Hrsg.). Karlsruher Kommentar zum Gesetz über Ordnungswidrigkeiten. 4. Auflage. München: C.H. Beck, 2014.

RÖNNAU, Thomas. Einrichtung "schwarzer" (Schmiergeld-) Kassen in der Privatwirtschaft - eine strafbare Untreue? In: SIEBER, Ulrich (Hrsg.). Strafrecht und Wirtschaftsstrafrecht: Dogmatik, Rechtsvergleich, Rechtstatsachen; Festschrift für Klaus Tiedemann zum 70. Geburtstag. Köln: Heymann, 2008. p. 713-736.

RÖNNAU, Thomas. Grundwissen - Strafrecht: Vorsatz. Juristische Schulung, [s.I.], v. 50, n. 8, p. 675-678, 2010.

RÖNNAU, Thomas. Haftung für unterlassene Aufsicht nach $\S 130 \mathrm{OWiG}$ und strafrechtlicher (Drittempfänger-)Verfall gemäß $§ 73$ Abs. 3 StGB - zwei bedeutsame Bedrohungsszenarien für Unternehmen. Zeitschrift für Unternehmens- und Gesellschaftsrecht, [s.I.], v. 45, n. 2/3, p. 384-413, 2016. DOI: 10.1515/zgr-2016-0277.

RÖNNAU, Thomas; TIEDEMANN, Klaus. §82. In: SCHOLZ, Franz (Hrsg). GmbHG: Kommentar. 11. Auflage. Köln: Verlag Dr. Otto Schmidt, 2015.

ROTSCH, Thomas. §4 (Originäre strafrechtliche Verantwortlichkeit). In: ROTSCH, Thomas (Hrsg.). Criminal Compliance. Baden-Baden: Nomos Verlag, 2015. p. 142 ss.

ROTSCH, Thomas. Criminal Compliance. In: ACHENBACH, Hans; RANSIEK, Andreas; RÖNNAU, Thomas (Hrsg.). Handbuch Wirtschaftsstrafecht. 4. Auflage. Heidelberg: C.F. Müller, 2015.

ROXIN, Claus. Strafrecht. Allgemeiner Teil: Grundlagen, der Aufbau der Verbrechenslehre. 4. Auflage. München: C.H. Beck, v. I, 2006.

ROXIN, Claus. Zur Normativierung des dolus eventualis und zur Lehre von der Vorsatzgefahr. In: ROGALL, Klaus (Hrsg.). Festschrift für Hans-Joachim Rudolphi zum 70. Geburtstag. Neuwied: Luchterhand, 2004. p. 243-257. (= Sobre a normativização do dolo eventual e a doutrina do perigo doloso. Trad. Eduardo Viana. Revista de Estudos Criminais, Porto Alegre, v. 19, n. 79, p. 7-27, 2020.)

SAMSON, Erich. Absicht und direkter Vorsatz im Strafrecht. Juristische Arbeitsblätter, [s.I.], p. 449-454, 1989.

SCHALL, Hero. Geschäftsherrenhaftung und Mobbing. In: HEGER, Martin; KELKER, Brigitte; SCHRAMM, Edward (Hrsg.). Festschrift für Kristian Kühl zum 70. Geburtstag. München: Beck, 2014. p. 417-432. 
SCHEMMEL, Alexander; KIRCH-HEIM, Claudio. "Willful Blindness" im Wirtschaftsstrafrecht - Kann gewollte Unwissenheit vor Strafe schützen? Corporate Compliance Zeitschrift, [s.I.], v. 1, n.8, p. 96-100, 2008.

SCHNEIDER, Hartmut. \$212. In: SANDER, Günther M. (Hrsg.). Münchener Kommentar zum Strafgesetzbuch. 2. Auflage. München: C.H. Beck, v. 4, 2012.

SCHNEIDER, Hartmut. Zur Annahme von Tötungsvorsatz bei Abgabe von Schüssen. In: WIDMAIER, Gunter; LESCH, Heiko; MÜSSIG, Bernd; WALLAU, Rochus (Hrsg.). Festschrift für Hans Dahs. Köln: Verlag Dr. Otto Schmidt, 2005, p. 189-206.

SCHROTH, Ulrich. Der bedingte Tötungsvorsatz im Spiegel der Rechtsprechung. In: SCHÖCH, Heinz (Hrsg.). Strafverteidigung, Revision und die gesamten Strafrechtswissenschaften: Festschrift für Gunter Widmaier zum 70. Geburtstag. Köln: Heymann, 2008. p. 779-799.

SCHROTH, Ulrich. Vorsatz als Aneignung der unrechtskonstituierenden Merkmale. Frankfurt am Main: Lang, 1994.

SCHÜNEMANN, Bernd. Vom philologischen zum typologischen Vorsatzbegriff. In: WEIGEND, Thomas; KÜPPER, Georg (Hrsg.). Festschrift für Hans Joachim Hirsch zum 70.Geburtstag am 11.April 1999. Berlin: De Gruyter, 1999. p. 363-378. (= Do conceito filológico ao conceito tipológico de dolo. Trad. Luís Greco e Ana Cláudia Grossi. In: SCHÜNEMANN, Bernd. Estudos de direito penal, direito processual penal e filosofia do direito. São Paulo: Marcial Pons, 2013. p. 127-141.)

SPINDLER, Gerald. Unternehmensorganisationspflichten: zivilrechtliche und öffentlich-rechtliche Regelungskonzepte. Köln: Heymann, 2001.

TIEDEMANN, Klaus. Wirtschaftsstrafrecht: Einführung und Allgemeiner Teil mit wichtigen Rechtstexten. 4. Auflage. München: Vahlen, 2014.

VOGEL, Joachim. §15. In: LAUFHÜTTE, Heinrich Wilhelm; RISSING-VAN SAAN, Ruth; TIEDEMANN, Klaus. Leipziger Kommentar Strafgesetzbuch. 12. Auflage. Berlin: De Gruyter, v. 1, 2007.

VOGEL, Joachim. Normativierung und Objektivierung des Vorsatzes? Goltdammer's Archiv für Strafrecht, [s.I.], v. 153, p. 386-389, 2006.

VOLK, Klaus. §2 (Der Allgemeine Teil des Wirtschaftsstrafrechts). In: VOLK, Klaus (Hrsg.). Münchener Anwaltshandbuch. Verteidigung in Wirtschaftsund Steuerstrafsachen. 2. Auflage. München: C.H. Beck, 2014. p. 38 ss.

WEGNER, Kilian. Betrugsstrafbarkeit bei Missbrauch des "WAP-Billing"-Verfahrens. Neue Zeitschrift für Strafrecht, [s.I.], p. 455-460, 2016. 
WELLER, Marc-Philippe. Wissenszurechnung in internationalen

Unternehmensstrafverfahren. Zeitschrift für Unternehmens- und Gesellschaftsrecht, [s.I.], v. 45, n. 2/3, p. 384-413, 2016. DOI: 10.1515/zgr-2016-0384.

WITTIG, Petra. Wirtschaftsstrafrecht. 3. Auflage. München: C.H. Beck, 2014.

ZIMMERMANN, Susanne Annette. Strafbarkeitsrisiken durch Compliance:

Auswirkungen von Compliance-Regelungen auf das Wirtschaftsstrafrecht. Berlin:

Duncker \& Humblot, 2014.

\section{Sobre os autores:}

Thomas Rönnau | E-mail: thomas.roennau@law-school.de

Doutor em Direito (Uni-Kiel/Alemanha). Professor titular de Direito Penal, Direito Penal Econômico e Direito Processual Penal (Bucerius Law School/Alemanha).

Christian Becker | E-mail: cbecker@europa-uni.de

Doutor em Direito (Bucerius Law School/Alemanha). Professor titular de Direito Penal, Direito Processual Penal e Filosofia do Direito (Europa-Universität Viadrina/Alemanha).

Recebimento: 24.11 .2021

Aprovação: 26.12 .2021

Artigo convidado 